Investigating mechanisms of angiogenesis in health and disease using zebrafish models

\author{
Zaheer Ali
}

Division of cardiovascular medicine (KVM)

Department of medical and health sciences (IMH)

Linköping 2018

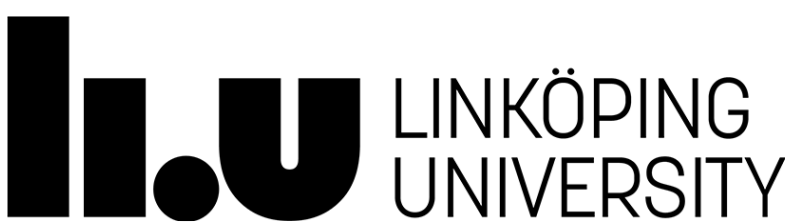


(C) Zaheer Ali

Cover image: by Zaheer Ali

Published articles have been reprinted with permission from the copyright holders.

Published by Linköping University

Printed by Liu-Tryck, Linköping, Sweden, 2018

ISBN: 978-91-7685-199-9

ISSN 0345-0082 


\section{Investigating mechanisms of angiogenesis in health and disease using zebrafish models}

Academic thesis by

Zaheer Ali

For the award of doctorate degree (PhD)

Division of cardiovascular medicine (KVM)

Department of medical and health sciences (IMH)

Linköping University

Linköping, Sweden

Examination held at

Belladonna

Friday, $14^{\text {th }}$ December 2018, 13:00

\author{
Main supervisor \\ Lasse Dahl Ejby Jensen, PhD, Docent \\ Assistant Professor \\ Department of \\ medical and health sciences (IMH) \\ Division of cardiovascular medicine (KVM) \\ Linköping University, Linköping, Sweden
}

\author{
Co-supervisor \\ Neil Lagali, PhD, Docent \\ Associate Professor \\ Department of clinical and experimental \\ medicine (IKE) \\ Division of Neuro and Inflammation \\ Sciences (NIV) \\ Linköping University, Linköping, Sweden
}

\section{Faculty Opponent}

Massimo Santoro, PhD, Docent

Professor

Department of Biology

University of Padua, Padua, Italy

\section{Examination board}

Zoltán Szabó, PhD, Docent

Assistant Professor

Department of

medical and health sciences (IMH)

Division of cardiovascular medicine (KVM)

Linköping University, Linköping, Sweden

Anita Öst, PhD, Docent

Senior Lecturer

Department of clinical and experimental

Medicine (IKE)

Division of neurobiology (NEUROB)

Linköping University, Linköping, Sweden

Johan Ledin, PhD, Docent

Associate Professor

Department of organismal biology

Uppsala University, Uppsala, Sweden

Magnus Grenegård, PhD, Docent

Professor

School of medical sciences

Örebro University, Örebro, Sweden 
"Everything is theoretically impossible, until it is done".

Robert A. Heinlein 


\begin{abstract}
Angiogenesis, the growth of blood vessels from an existing vasculature, can occur by sprouting from preexisting vessels or by vessel splitting (intussusception). Pathological angiogenesis drives choroidal neovascularization (CNV) in age related macular degeneration (AMD) which is commonly restricted under the retinal pigment epithelium (RPE), called occult CNV, but may also involve vessels penetrating through the RPE into the sub-retinal space. Pathological vessels are poorly developed, insufficiently perfused and highly leaky, phenotypes that are considered to drive disease progression and lead to poor prognosis. Currently, a number of anti-angiogenic drugs exists, the majority of which target vascular endothelial factor (VEGF), but although they often are highly beneficial for treating eye diseases in the short-term, they are generally of limited efficacy in other diseases such as cancer, and also have poorer efficacy when used for treatment of eye diseases in the long-term. A better understanding of the mechanisms underlying pathological angiogenesis can generate new targets for treatment leading to development of better drugs for cancer and retinopathies, but perhaps also other angiogenesis-dependent diseases, in the future. In this thesis mechanisms involved in developmental angiogenesis or pathological angiogenesis in the choroid, cornea or melanoma was identified. These findings highlight the need to further elaborate our knowledge related to angiogenesis in different tissues/conditions for a more targeted, and potentially effective treatment of diseases in the future.
\end{abstract}

In paper I, we for the first time identified the choriocapillaries (CCs) in adult zebrafish and found that occult CNV could be induced by exposing the fish to severe hypoxia. Interestingly, we found that occult CNV relied on intussusception, involving not only de novo generation of intussusceptive pillars but also a previously poorly understood mechanism called pillar splitting. This involved HIF-VEGF-VEGFR2 signaling and evidence that this also occurred in both rats and humans suffering from AMD suggested that the mechanism was conserved and clinically relevant.

In contrast, we found in paper II that the development of CCs in the zebrafish relies on sprouting angiogenesis, involve continuous remodeling, and delayed maturation of the vasculature in 2D. The initial development was found to occur by a unique process of tissuewide synchronized vasculogenesis. As expected, VEGFA via VEGFR2 was also critical for the development of these vessels in the zebrafish embryo, but surprisingly this was independent on hypoxia-inducible factor (HIF)-1.

Inflammatory nuclear factor-kB (NF-kB) signaling is involved in the progression of angiogenesis, but this signaling pathway has mainly been studied in the inflammatory cells and the role of NF-kB in the endothelial cells during angiogenesis is poorly understood. In paper III, we found that blocking NF-kB signaling using a specific IKK2 blocker IMD0354, specifically blocks pathological as well as developmental angiogenesis by targeting endothelial cell NF-kB signaling in the endothelial cells. Using a rat model for suture-induced corneal neovascularization, IMD0354 treatment lead to reduced production of inflammatory C-C motif 
chemokine ligand 2 (CCL2), C-X-C motif chemokine ligand 5 (CXCL5) and VEGF, and thereby reduced pathological corneal angiogenesis in this model.

Using the zebrafish tumor xenograft model in paper IV, we found an association between Microphthalmia associated transcription factor (MITF) and pigment epithelium derived factor (PEDF), which was involved in pathological tumor angiogenesis and metastasis. Similarly, in paper $\mathrm{V}$ we used zebrafish transplantation models to study and investigate the use of biocompatible polymers for the delivery of pro-angiogenic FGF-2 as a potential treatment strategy for ischemic diseases such as myocardial infarction (MI). Conclusively, this thesis provides new insights into diverse fields of angiogenic assays using zebrafish, and reveals new mechanisms of angiogenesis in health and disease. This work will hopefully provide a foundation for further studies into occult CNV related to AMD, a process that has not been possible to study previously in pre-clinical models. In addition, zebrafish xenograft or other transplantation models used in this work will likely be important to study cancer biology and to develop more attractive pharmaceutical preparations based on biocompatible hydrogels formulated as microspheres in the future. 


\section{Sammanfattning}

Blodkärlstillväxt spelar en central roll vid båda hälsa och sjukdom. Under embryonal utveckling, underhåll av kroppens organ i vuxen ålder och för regeneration vid exempelvis sårläkning, stroke och hjärtinfarkt ingår blodkärlstillväxt som ett viktigt element $\mathrm{i}$ dessa processer. Blodkärlstillväxt är även nödvändig för uppkomst och utveckling av folksjukdomar som cancer, diabetes ögonsjukdom och gula fläcken. I båda hälsa och sjukdom är syrebrist och inflammation de två vanligaste signaler för blodkärlstillväxt. Efter aktivering växer blodkärlen genom att bilda skott som bryter ut ifrån existerande kärl och växer in i den kringliggande vävnaden. Alternativt delas kärlen på mitten och på så vis fördubblas. I sjukt vävnad pågår detta så snabbt att de växande blodkärl inte hinner mognas. Detta innebär att kärlen är försvagade och läcker ut väska som ansamlas i vävnaden. I cancer är denna typ av omogna blodkärl nära kopplad till båda tumörtillväxt och metastas. I ögonsjukdomar är blodkärlsläckaget istället kopplat till blåsbildningar eller blödningar i ögat som ökar nedbrytningstakten av syncellerna. Det finns idag medicin som är inriktad emot sjukdomsfrämjande blodkärlstillväxt men då många patienter inte svara tillräcklig väl eller bara svara i en kortare period för sedan att bli resistenta, behövs nya läkemedel för dessa patientgrupper.

I denna avhandling har blodkärlstillväxt processen undersökts under utvecklingen av ögonsjukdomarna "gula fläcken" och kärltillväxt i hornhinnan (artikel I och III), under den embryonala utvecklingen av ögat (artikel II) och under metastasering av cancerceller (artikel IV). Det har även utvecklats nya sätt att leverera faktorer som påverkar blodkärlstillväxt genom att koppla dessa till biomaterialer som på ett kontrollerat sätt kan frisätta dessa faktorer på platsen där de behövs (artikel V). I dessa arbeten användes zebrafisk modeller som har inneburit nya möjligheter att studera processer som reglera blodkärlstillväxt jämfört med vad som har varit möjligt tidigare i andra djurmodeller, och därför bidragit med viktig nu kunskap om de tidiga, första stegen i blodkärlstillväxtprocessen.

I artikel I identifierades för första gången kärInätverket åderhinnan, kärlnätverket som finns direkt bakom näthinnan och därför i nära anslutning till syncellerna, i vuxna zebrafiskar. Åderhinnan svarade på syrebrist men i motsättning till de existerande modellerna för åderhinna tillväxt $\mathrm{i}$ gnagare, växte kärlen i syrebrist-påverkade zebrafiskar inte växte in $i$ näthinnan, och inte bildade kärlskott, utan istället delade på sig. Denna process upptäcktes också i biopsier från patienter med gula fläcken, och ger därför ny insikt om hur vi kan undersöka och eventuellt behandla patienter i ett tidigare sjukdomsskede i framtiden.

I artikel II undersöktes kärlbildningen i åderhinnan under embryonal utveckling i detalj. Genom avancerad mikroskopi upptäcktes att detta hände på ett organiserat sätt i hela ögat samtidigt, och enbart $i$ ett två-dimensionellt plan, vilket är olika hur blodkärlen utvecklas $i$ andra vävnader. Detta var viktigt för att bilda åderhinnans unika form och funktion. Båda under embryonal utveckling och i vuxna fiskar var kärltillväxten i åderhinnan beroende av tillväxtfaktorn VEGF och dess receptor VEGFR2. 
I artikel III upptäcktes att inflammation även påverkar endotelcellerna som bilder den inre delen av blodkärlen, något som tidigare har varit dåligt undersökt. Inflammationsfaktorn NFkB var viktig för bildning av VEGF och blodkärlstillväxt båda när celler studerades i cellodling, under embryonal utveckling i zebrafiskar och i vuxna råttor. I artikel IV undersöktes en ny mekanism för metastas som grundades i faktorerna MITF och PEDF, vilka försvårade för blodkärlstillväxt och metastas i hudcancer. I detta arbete användes genetisk modifierade cancerceller som implanterades i zebrafisk embryon, ett nytt och spännande sätt att undersöka den tidiga metastaseringsförmågan av cancerceller.

I artikel V etablerades en ny metod för att bilda mikrosfärer av ett biomaterial som utvecklades så att terapeutiska faktorer kunna frisättas på ett kontrollerat sätt över tid. Dessa nya material hoppas vi på sikt kan användas till utvecklig av nya metoder att främja läkning och återbildning av skadad vävnad, exempelvis hjärtvävnad efter en hjärtinfarkt.

Genom dessa arbeten, och den utökade diskussionen i kappan, bidra denna avhandling till ökat insikt i mekanismerna som reglera blodkärlstillväxt i ögat, tumörer och under embryonal utveckling. Dessutom har vi för att möjliggöra detta etablerat ett flertal nya verktyg, baserade på zebrafisk modeller och nya system för att framställa biomaterial som kan användas kliniskt. Dessa nya verktyg och kunskaper bilder en stark grund för att upptäcka nya behandlingsmål och utveckla nya läkemedel mot vanliga, men mycket alvarliga folksjukdomar som gula fläcken, kärltillväxt i hornhinnan, cancer och hjärtinfarkt i framtiden. 


\section{List of Publications included in this thesis}

I. Ali Z, Mukwaya A, Biesemeier A, Ntzouni M, Ramsköld D, Giatrellis S, Mammadzada P, Cao R, Lennikov A, Marass M, Gerri C, Hildesjö C, Deng Q, Peebo B, Peso L, Kvanta A, Sandberg R, Schraermeyer U, Andre H, Steffensen JF, Lagali N, Cao Y, Kele J and Jensen LD. Intussusceptive vascular remodeling precedes pathological neovascularization. Submitted

II. Ali Z, Cui D, Yang Y, TW Dhani, Rodriguez GV, Moosajee M, Ju R, Li X, Cao Y, Jensen LD. Synchronized tissue-scale vasculogenesis and ubiquitous lateral sprouting underlie the unique architecture of the choriocapillaris. In Press, Developmental Biology

III. Lennikov A, Mirabelli P, Mukwaya A, Schaupper M, Thangavelu M, Lachota M, Ali Z, Jensen L, Lagali N: Selective IKK2 inhibitor IMD0354 disrupts NF-KB signaling to suppress corneal inflammation and angiogenesis. Angiogenesis 2018, 21:267-85.

IV. Fernández-Barral A, Orgaz JL, Baquero P, Ali Z, Moreno A, Tiana M, Gómez V, RiveiroFalkenbach E, Cañadas C, Zazo S, Bertolotto C, Davidson I, Rodríguez-Peralto JL, Palmero I, Rojo F, Jensen LD, del Peso L, Jiménez B: Regulatory and Functional Connection of Microphthalmia-Associated Transcription Factor and Anti-Metastatic Pigment Epithelium Derived Factor in Melanoma. Neoplasia 2014, 16:529-42.

V. Ali Z, Islam A, Sherrell P, Le-Moine M, Lolas G, Syrigos K, Rafat M, Jensen LD: Adjustable delivery of pro-angiogenic FGF-2 by alginate:collagen microspheres. Biology Open 2018, 7 . 


\section{Related publications not included in this thesis}

I. Ali Z, Wang J, Cao Y, Jensen LD: Methods for Studying Developmental Angiogenesis in Zebrafish. Handbook of Vascular Biology Techniques. Edited by Slevin M, McDowell G. Dordrecht: Springer Netherlands, 2015. pp. 195-207.

II. Ali Z, Jensen LD: Hypoxia-Induced Retinal Angiogenesis in Adult Zebrafish. Handbook of Vascular Biology Techniques. Edited by Slevin M, McDowell G. Dordrecht: Springer Netherlands, 2015. pp. 173-83.

III. Ali Z, Jensen LD: Angiogenesis in the Regenerating Adult Zebrafish Tail Fin. Handbook of Vascular Biology Techniques. Edited by Slevin M, McDowell G. Dordrecht: Springer Netherlands, 2015. pp. 185-93.

IV. Mukwaya A, Peebo B, Xeroudaki M, Ali Z, Lennikov A, Jensen L, Lagali N: Factors regulating capillary remodeling in a reversible model of inflammatory corneal angiogenesis. Scientific Reports 2016, 6:32137.

V. Mukwaya A, Lindvall JM, Xeroudaki M, Peebo B, Ali Z, Lennikov A, Jensen LDE, Lagali $\mathrm{N}$ : A microarray whole-genome gene expression dataset in a rat model of inflammatory corneal angiogenesis. Scientific Data 2016, 3:160103.

VI. Ali Z, Zang J, Lagali N, Neuhauss S, Jensen LD* and Kimmel RA*. Photoreceptor degeneration accompanies vascular changes in a zebrafish model of diabetic retinopathy. Manuscript

* denotes equal contribution

VII. Ali Z\#, Soto VS\#, Johansson S, Akhtar SUB, Lindqvist E, Cao Y, Jensen LD. Hypoxiainduced acute blood-brain barrier disruption occurs by vascular dilation-mediated trans-endothelial leakage in adult zebrafish. Manuscript

\# denotes equal contribution

VIII. Karjosukarso DW, Ali Z, Peters TA, Zhang JQC, Wijk EV, Jensen LD*, Collin RWJ*. Modeling ZNF408-associated FEVR in zebrafish results in abnormal retinal vasculature. Manuscript

* denotes equal contribution

IX. Ward R, Reynolds AL, Slater K, Ali Z, Jensen LD, Kennedy BN. Pharmacological restoration of visual function in a zebrafish model of von-Hippel Lindau disease. Submitted

X. Sun XF, Liu N, Cui W, Jiang X, Zhang Z, Gnosa S, Ali Z, Jensen LD, Jönsson JI, Blockhuys $S$, Lam E, Zhao Z, Ping J, and Wang X. The critical role of dysregulated RhoB signaling pathway in radioresistance of colorectal cancer. Submitted 
CONTENTS

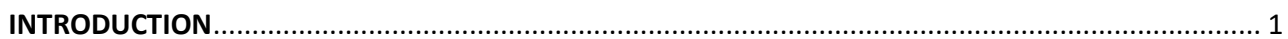

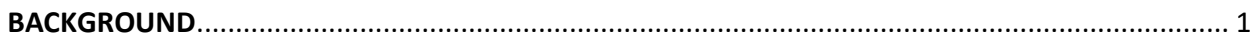

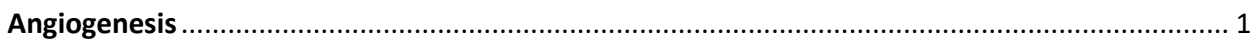

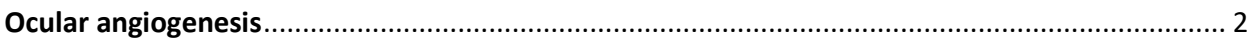

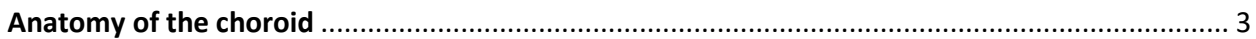

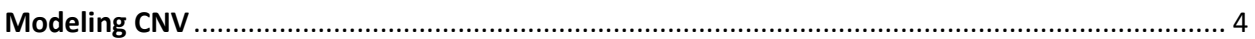

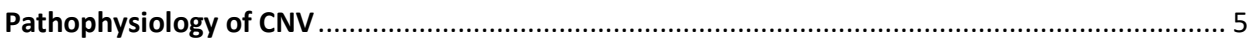

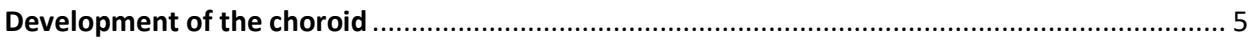

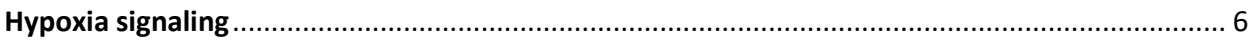

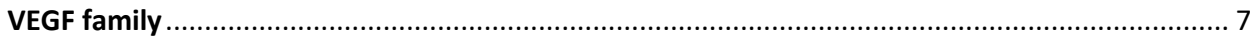

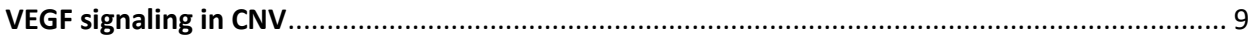

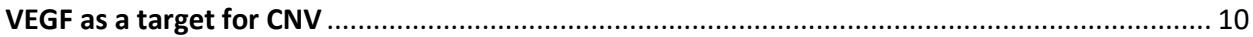

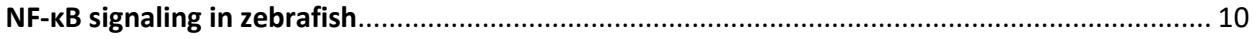

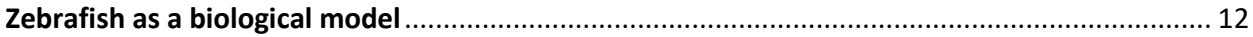

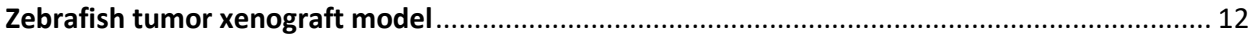

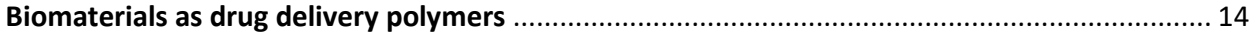

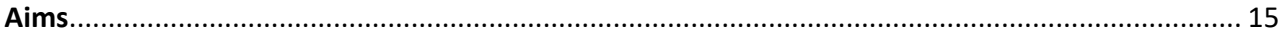

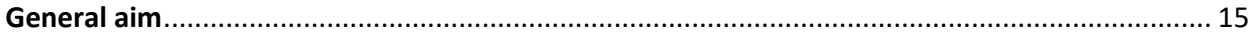

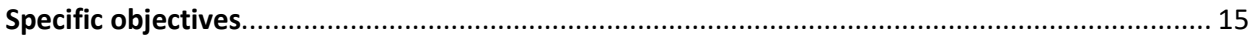

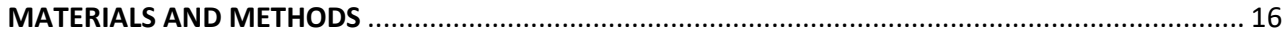

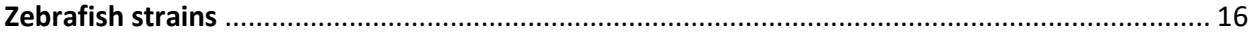

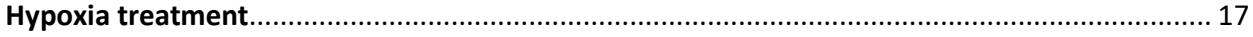

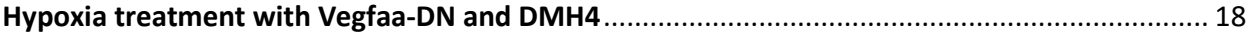

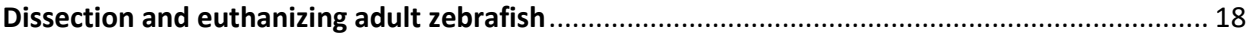

Vascular leakiness evaluation in the choriocapillaris.................................................... 19

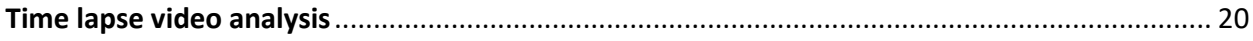

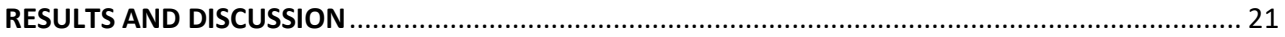

Identification of pathological vessel remodeling in the choroidal vessels of adult zebrafish (Paper

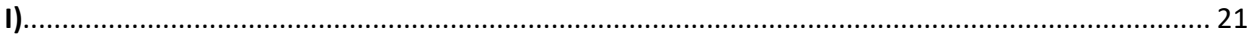

Development of choriocapillaris occurs by vasculogenesis and sprouting angiogenesis in the zebrafish whereas the structural similarity remain the same as in mouse (Paper II)

Inhibiting NF-kB inflammatory pathway with a selective IKK2 blocker, IMD0354 inhibits angiogenesis (Paper III) 
Understanding the interlinked connections between microphthalmia associated transcription factor (MITF) and pigment epithelium derived factor (PEDF) using tumor cell dissemination model of zebrafish (Paper IV)

Alginate and collagen hydrogels provide a reliable therapeutic alternative for drugs and cells delivery (Paper V)

DISCUSSION..

CONCLUSIONS 33

ACKNOWLEDGEMENTS

REFERENCES

Appendix: Publications and manuscripts used in this thesis 49 


\section{ABBREVIATIONS}

\begin{tabular}{|c|c|}
\hline AMD & Age related macular degeneration \\
\hline ARNT & Aryl hydrocarbon nuclear translocator \\
\hline $\mathrm{CCs}$ & Choriocapillaris \\
\hline CNV & Choroidal neovascularization \\
\hline CBP & CREB binding protein \\
\hline CCV & Common cardinal vein \\
\hline DR & Diabetic retinopathy \\
\hline ECs & Endothelial cells \\
\hline FACS & Fluorescence-activated cell sorting \\
\hline $\mathrm{FIH}$ & Factor inhibiting HIF \\
\hline HIF & Hypoxia inducible factor \\
\hline MAPK & Mitogen-activated protein kinase \\
\hline MI & Myocardial infarction \\
\hline MITF & Microphthalmia associated transcription factor \\
\hline NF-KB & Nuclear factor кВ \\
\hline PEDF & Pigment epithelium derived factor \\
\hline PFA & Paraformaldehyde \\
\hline PHD & Prolyl hydroxylase enzyme \\
\hline PI3-K & Phosphatidylinositol 3-kinase \\
\hline PVS & Peri-vitteline space \\
\hline qPCR & Quantitative polymerase chain reaction \\
\hline RHD & Rel homology domain \\
\hline RM & Rete mirabile \\
\hline RNA & Ribonucleic acid \\
\hline ROP & Retinopathy of prematurity \\
\hline ROS & Reactive oxygen specie \\
\hline RVs & Retinal vessels \\
\hline SEM & Scanning electron microscope \\
\hline TEM & Transmission electron microscope \\
\hline VEGF & Vascular endothelial growth factor \\
\hline VEGFA-DN & Vascular endothelial growth factor dominant negative \\
\hline VEGFR & Vascular endothelial growth factor receptor \\
\hline VHL & Von Hippel-Lindau \\
\hline
\end{tabular}





\section{INTRODUCTION}

\section{BACKGROUND}

Pathological neovascularization in the eye is an important step towards development of diseases such as cancer, age related macular degeneration (AMD), diabetic retinopathy (DR) and retinopathy of prematurity (ROP) ${ }^{1}$. Neovascularization in the retinal vessels underlies the aggressive form of DR called proliferative (P)DR ${ }^{2}$ while choroidal neovascularization (CNV) is a major complication of AMD, leading to exudative or "wet" AMD, which can ultimately lead to blindness. Currently, AMD is un- or undertreated because of the involvement of many factors such as age and molecular factors. It is of prime importance to study these diseases, by establishing animal models for these diseases and ultimately develop exact treatment strategies $^{3}$. In AMD and DR, the angiogenic induction in the back (choroid) or front (retina) of the eye respectively, constitute a switch to severe disease with rapidly decreasing visual acuity and eventually leading to blindness, unless treated ${ }^{4}$. Little is known about the mechanisms regulating pathological ocular angiogenesis in AMD or DR. In AMD, pathological angiogenesis occurs subsequent to accumulation of cellular debris in the choroid, and in DR chronically elevated blood glucose is the underlying responsible factor. In both cases, however, the molecular and cellular changes involved in initial or ongoing angiogenic induction are poorly understood. Furthermore, healthy growth of blood vessels in the eye during development has also been poorly studied from a mechanistic point of view, especially in the choroid.

Biomaterials are not harmful for the body and serve a very important role as therapeutic delivery vehicles or scaffolds used in the regenerative medicine ${ }^{5}$. Unlike zebrafish, which can regenerate its own heart ${ }^{6,7}$, humans don't have the ability to regenerate their hearts. For example, patients suffering from myocardial infarction (MI) or other cardiovascular disorders such as congenital cardiovascular disorders, biomaterial assisted patching material is used for the augmentation of the functional recovery of the injured cardiovascular tissues ${ }^{8}$. Similarly, defects in the heart valves could be treated with replacement of the defective heart valve with a synthetic heart valve made of biocompatible biomaterial ${ }^{8,9}$. Another approach to use these biomaterials is to repair abnormal blood vessels with a procedure called vascular grafts ${ }^{8}$. Another important use of biomaterials is to use suture ${ }^{10}$ and medical textile products ${ }^{8}$.

\section{Angiogenesis}

Angiogenesis is the development of newly formed vessels from the existing vessels. There are 2 major mechanisms of angiogenesis; one is sprouting angiogenesis while the other is known as intussusceptive angiogenesis (Figure 1). Early development involves intensive angiogenesis and remodeling of the vessels, which is very important because that is required for the normal development of the tissues. In order to generate a vascular scaffold for angiogenesis another process, vasculogenesis, leads to the de novo formation of the first vessels during early development ${ }^{11}$. In contrast pathological angiogenesis is associated with different diseases and is well known to play important roles in particular during cancer development, wet AMD, and PDR. 


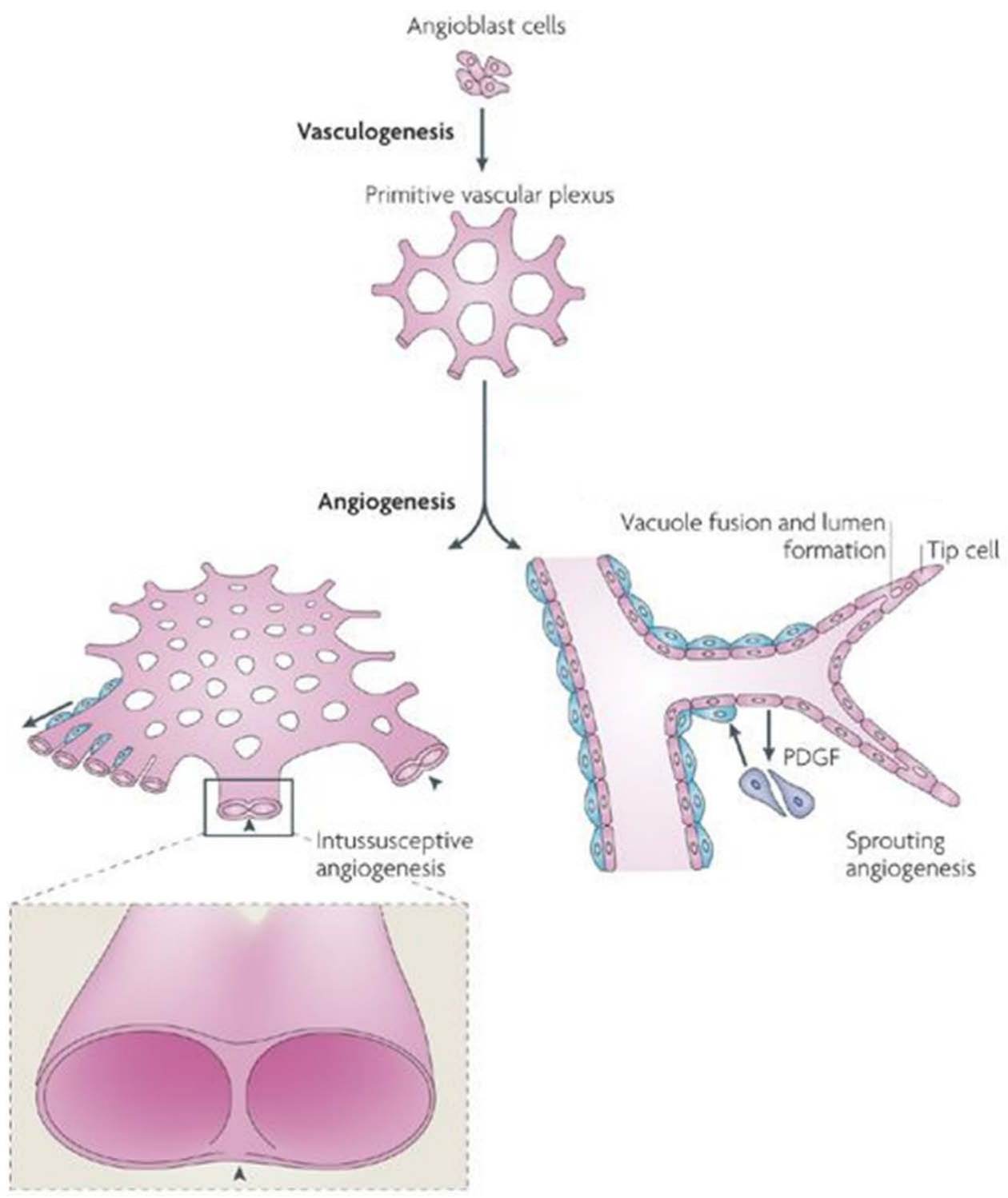

Figure 1. Schematic representation of vasculogenesis, intussusception and sprouting angiogenesis. Primitive plexus of capillaries are formed as a first step towards differentiation of angioblast from the endothelial cells. Further development of these capillaries is followed by intussusceptive angiogenesis in the left block of the figure and sprouting angiogenesis on the right block. Intussusception involves splitting of a capillary into two or more while the sprouting involves extension of the preexisting capillary by stalk cells following a tip cell. PDGF. Platelet derived growth factor. Downloaded and modified with permission from ${ }^{12}$.

\section{Ocular angiogenesis}

Pathological angiogenesis in the eye can lead to blindness. It can occur in retinal vessels during development in the form of retinopathy of prematurity (ROP), or diabetic retinopathy (DR) in case of adult diabetic patients. Wet AMD (explained later) in turn results from pathological 
changes in the choriocapillaries found in particular in the elderly population. In the cornea the outer part of the eye, neovascularization of this normally avascular tissue can lead to blindness. These are classical examples of the majority of the eye problems affecting hundreds of millions human beings.

\section{Anatomy of the choroid}

The choroid is the most densely vascularized layer of the eye. It is vulnerable to many pathologies, of which the most important is AMD. AMD has 2 subtypes wet AMD and dry AMD. The choroid vasculature is involved in both, but in different ways: choroidal vascular degeneration leads to dry AMD and pathological growth into the sub-retinal or retinal space is involved in wet AMD. The choroid is located between the retina and the sclera ${ }^{13}$ (Figure 2 ). One of the most important functions of the choroid is to supply oxygen and nutrients to the photoreceptors and other cell types in the outer retina. This function is crucial; lacking oxygen or nutrients in the outer retina could lead to (dry) AMD, or other retinal degenerative diseases in younger individuals. Another interesting aspect of the choroid is to regulate the temperature in the retina ${ }^{13,14}$. In addition to these important functions, the thickness of the choroid is also very important because thicker choroid push the retina forward to allow adjustments of the lens for the better focus and vice versa, meaning that pathologically thickened choroids could ultimately affect focus ${ }^{15}$. The choroid comprises of 4 different layers. The first 2 layers adjacent to the retinal pigment epithelium, just posterior to the retina, are known as Haller's and Sattler's layers respectively ${ }^{14}$. The most vascularized layer in the choroid is the highly dense choriocapillaris, adjacent to the Bruch's membrane (BM) (Figure 2). 
A
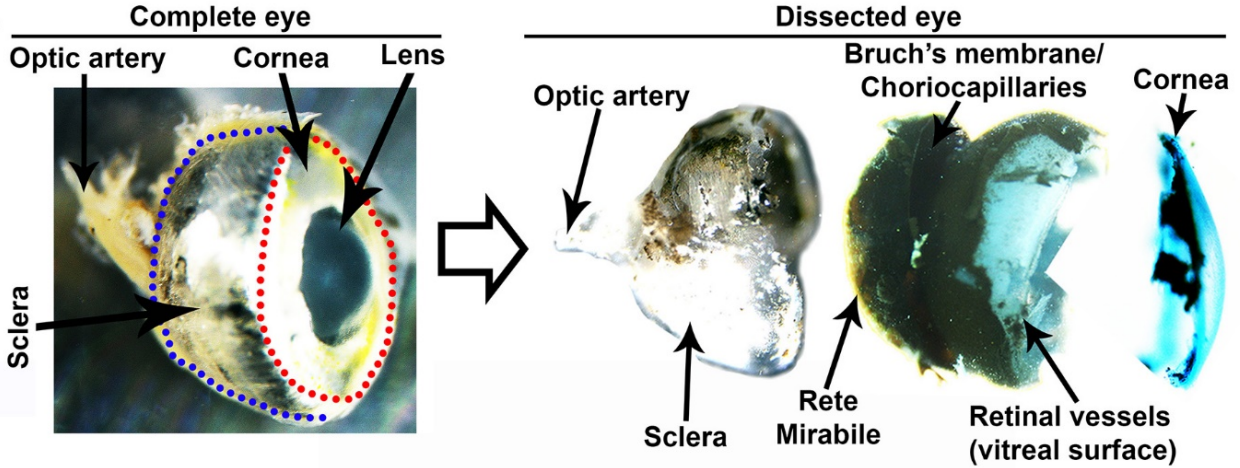

B
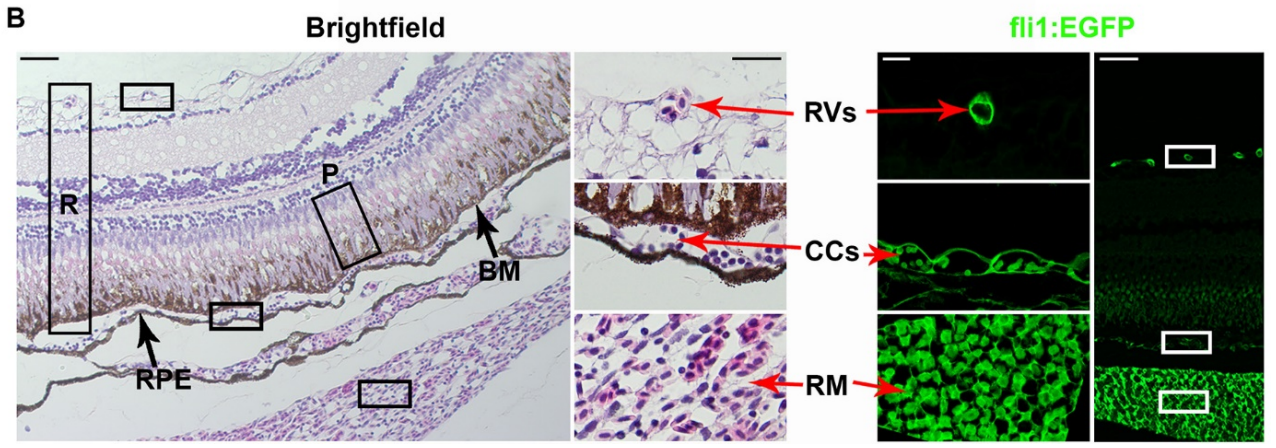

Figure 2. Anatomy of the zebrafish eye. A. A complete non-dissected eye on the left panel showing location of sclera, optic artery, cornea and lens. Right panel shows a dissected eye showing exact location and orientation of these tissues. Choroid comprising rete mirabile (RM) and choriocapillaris (CCs) is located centrally between sclera and retina, covered with outermost layer the cornea. B. Paraffin embedded sections stained with hematoxylin and eosin (H\&E) of the zebrafish eye on the left panel showing retina, CCs and RM while confocal micrographs of vessels (shown in green) in the $\mathrm{Tg}$ (fli1a:EGFP reporter strain shown in the right panel. Boxed images are magnified in both panels to the right and left respectively. Size bars indicates $20 \mu \mathrm{m}$ in low and 50 $\mu \mathrm{m}$ in high magnification images in both panels. R. Retina, P. Photoreceptors, RPE, Retinal pigment epithelium, BM, Bruch's membrane.

\section{Modeling CNV}

Choroidal neovascularization (CNV) is a severe complication, which arise from leaky, disrupted neo-vessels in the choroid. It is one of the major vision loss complications associated with latestage AMD ${ }^{16,17}$. CNV in AMD is further divided in 2 major types i.e, CNV through the retinal pigment epithelium (RPE) is known as "classic CNV" ${ }^{18}$ while CNV under the RPE is called "Occult CNV" 19. It is estimated that over 50 million people are suffering worldwide from the occult form of CNV, which is the most common of the two sub-types ${ }^{20}$. In patients, early CNV is detected with the help of fluorescin angiography (FA), optical coherence tomography (OCT) as well as through a functional test where the patients will read straight lines as curly ${ }^{21}$. While in the later stages of CNV the sight of the patients are even worse ${ }^{21}$ and the newly formed vessels could pass through the Bruch's membrane into the retina. For a very long time, the only treatment available was photo coagulation therapy ${ }^{22}$ but with associated adverse side effects including reduced thickness and increased damage to the retina the, coagulation 
therapy is not the best treatment today. Instead photodynamic and anti angiogenic drugs therapy is currently recommended as first-line therapy ${ }^{17}$, of which the latter is the most commonly used form of treatment.

\section{Pathophysiology of CNV}

Wet AMD involves CNV ${ }^{23}$, due to extended formation of the abnormal blood vessels, the disease is very severe. The exact cause or the mechanism of CNV in AMD in not known ${ }^{24}$, however there are several lines of evidence and symptoms which can describe the development of the complications over time.

AMD affects mostly the elderly population with the histology of the choroid showing thickening of the choroid and Bruch's membrane, associated with a buildup of extra-cellular debris-depots called drusen, which eventually leads to the growth of newly formed vessels because of hypoxia-induced gradients of angiogenic factors arising between the outer retina and the choriocapillaries ${ }^{25-29}$. Some research studies have suggested degradation of the Bruch's membrane occurs by enzymatic activity ${ }^{30}$ as an important part in the pathophysiology of the disease. It could also be associated with an inflammatory response where inflammatory cells such as macrophages migrate to and surround the Bruch's membrane resulting in its degradation ${ }^{31}$. Another important factor promoting CNV, is driving and promotion of endothelial cell migration with the support of smooth muscle cells towards the damaged tissues in the overlaying retina ${ }^{24}$.

There are several other risk factors which contributes towards CNV such as persistent systemic hypertension, smoking, Caucasian race, old age etc. ${ }^{32}$. Among the other risk factors, oxidative stress, exposure to light and previous family history also play an important role in CNV promoting AMD. The use of zinc, Vitamin A, C and $E$ has been shown to reduce the risk of wet AMD by $20-25 \%$, which suggests a potential role of reactive oxygen species ${ }^{24}$. There has been no clue towards the exact risk factors for AMD and that is why this area should be further investigated. Involvement of many genes in the development of AMD makes the disease more complex. Several studies suggest involvement of mutations in AMD-associated genes ${ }^{33-37}$. Mutations in the ATP-binding cassette (ABC)-transporter gene, has been shown to have a close correlation to development of $A M D^{38}$. Coupling AMD with mutation in a specific gene is still very difficult because there is involvement of many other genes. Furthermore, AMD is a late stage disease with additional factors including social and environmental factors, which further hinders investigation of the onset of the disease.

\section{Development of the choroid}

Thickness of the choroid changes with age in all organisms, in humans; it changes from 200 $\mu \mathrm{m}$ at the birth to $80 \mu \mathrm{m}$ at adulthood ${ }^{14}$. In humans choroid development begins at the $7^{\text {th }}$ week of gestation. At 15 weeks the arterioles and venoles can be clearly seen and differentieated. Interestingly the structure at this age is already similar to that of the adult choroid ${ }^{39}$. In comparsion to the retinal vessels, which have blood-brain barrier function, the choriocapillaris do not; choriocapillaries are fenestrated to allow transport of macromolecules and cell remnants in and out of the posterior eye ${ }^{40}$. Development of the choroidal vessels is via angiogensis, which includes two main types, sprouting angiogenesis and intussuceptive 
angiogensis (Figure 1). The mode of choroidal development is believed to be sprouting angiogenesis in humans ${ }^{41}$ and other vertebrates while intussusception has been shown in the birds ${ }^{42-44}$.

\section{Hypoxia signaling}

There are 2 types of metabolism; aerobic which is in the presence of oxygen (normoxia) and anaerobic which is in the absence of oxygen (hypoxia). In a hypoxic condition with lower concentration of oxygen at less than $\mathrm{p} 21 \% \mathrm{O}_{2}$ there is not enough oxygen for the normal metabolism of the cell. A hypoxic condition is defined as a condition of insufficient oxygen. The actual oxygen concentration needed is different between the tissues - some tissues need a lot whereas others need very little. Therefore, the oxygen concentration required for hypoxia is also different between tissues. Blood vessels release nitric oxide as an acute repose to hypoxia leading to dilation of the vessels to fulfill the oxygen demand ${ }^{45}$. During more prolonged states of hypoxia, there are certain pathways which are activated, the most well studied involving the transcription factor hypoxia inducible factor (HIF1) ${ }^{46}$ (Figure 3). HIF1 is a heterodimer made of 2 subunits HIF1 $\alpha$ and HIF1 ${ }^{47}$. HIF1 and the related HIF2 are best known for their angiogenic properties ${ }^{48,49}$. Their expression is different in different locations HIF1 $\alpha$ being expressed universally and HIF2 $\alpha$ expressed in a population of cells only ${ }^{48}$. HIF1 $\beta$ is also known as Aryl hydrocarbon nuclear translocator (ARNT), and is similarly expressed universally. HIF1 $\alpha$ is the oxygen sensing part of the HIF family because of its stabilization in the hypoxic cells. Genes activated by hypoxia contains HIF1 binding sites known as HIFresponsive elements (HREs) ${ }^{50}$. Under normoxic conditions, a group of enzymes catalyze the destruction of HIF1 $\alpha$ and are called prolyl hydroxylase enzymes (PHDs) due to their hydroxylation properties. Von Hippel-Lindau (VHL) is an E3 ubuiquitin ligase complex which ubiquitinylates the hydroxylated HIF1 leading to its degradation by the proteasome, causing HIF1 to not be active in normal physiological conditions ${ }^{51}$. Loss of the function of VHL leads to activation of HIF1 and ultimately an angiogenic response in the tissue. activated HIF1 will activate transcription factors such as VEGF and PDGF leading to angiogenesis ${ }^{52,53}$. There is another factor called factor inhibiting HIF (FIH) which is oxygen dependent just like PHDs, and inhibit the transcriptional activity of HIF1 ${ }^{54}$.

The exact mechanism by which HIF1 $\alpha$ is activated via hypoxia is still unknown. Some studies suggest that the lack of signaling transduction pathways are involved ${ }^{55}$. This fact is based on the diminished activity of PHDs in hypoxia with decreased hydroxylation of the HIF1 $\alpha$ protein ${ }^{56}$ this will inhibit binding VHL to HIF1 $\alpha$ and in this way stabilize HIF1 $\alpha$. Some other studies suggest involvement of the signaling cascades such as sumoylation, diacylglycerol kinase, reactive oxygen species (ROS) and phosphatidylinositol 3-kinase (PI3-K)/ AKT 57-60. This suggests that PHDs are not only the regulators of this signaling pathway but also there is a need of other signaling pathways which are required in hypoxia ${ }^{60}$. Another important signaling pathway which is $\mathrm{p} 38 \alpha$ mitogen-activated protein kinase (MAPK) is believed to downregulate HIF1 $\alpha$ in hypoxic conditions when inhibited pharmacologically ${ }^{61,62}$. Details of HIF signaling pathway is presented in Figure 3. 


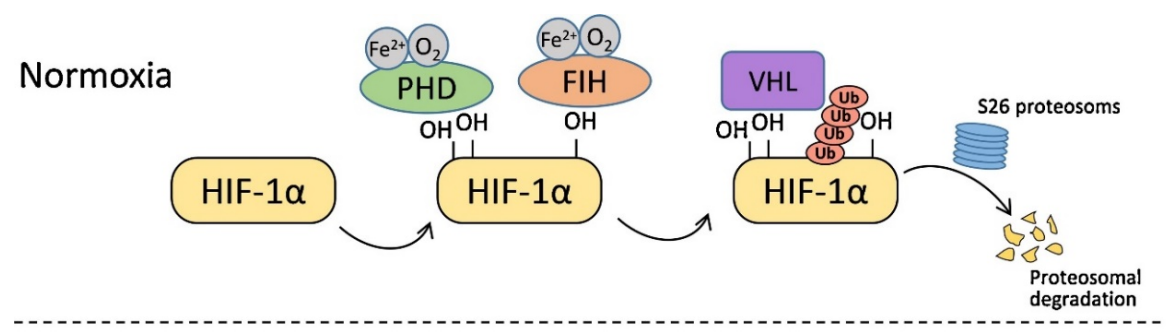

Hypoxia

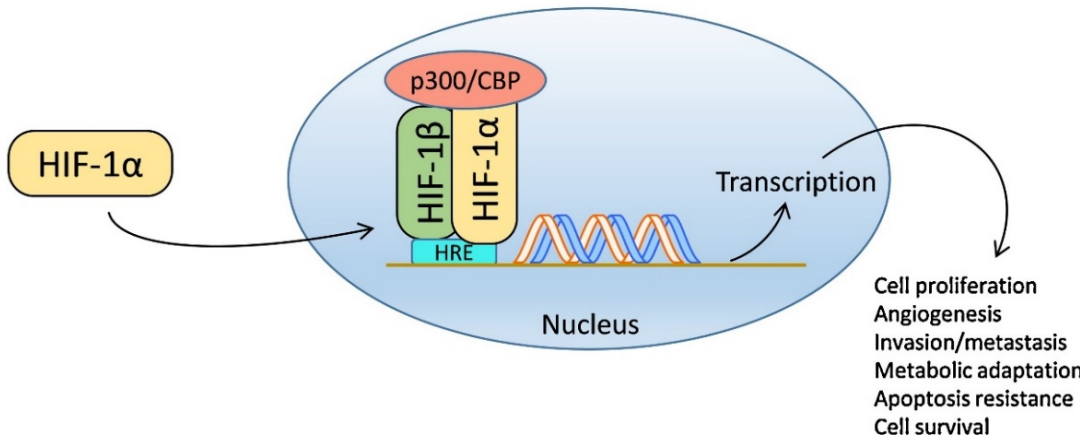

Figure 3. HIF1 signaling in normoxia and hypoxia. HIF1 $\alpha$ is stabilized under normoxic condition by PHDs in the presence of $\mathrm{Fe}^{2+}$ and $\mathrm{O}_{2}$ as substrate and as a cofactor respectively. Ubiquitination is enhanced by $\mathrm{VHL}$ and target HIF1 for degradation. FIH-hydroxylation further stops the binding of HIF1 $\alpha$ and HIF1 $\beta$ to the co-activators p300 and $\mathrm{CBP}$, leading to impaired transcriptional activity. Alternatively, during hypoxic conditions HIF1 $\alpha$ is translocated in the nucleus resulting in dimerization of HIF1 $\alpha$ and Hif1 $\beta$, recruitment of p300, CBP and binding to HREs at target genes which are generally activated by this complex. This complex thereby activate specific genes which will further activate pathological activities such as, cell proliferation, angiogenesis, metastasis, apoptosis resistance, survival and metabolic adaptation. HIF1 $\alpha$. Hypoxia inducible factor $1 \alpha$, HIF1 $\beta$. Hypoxia inducible factor $1 \beta, \mathrm{Fe}^{2+}$. Iron, $\mathrm{O}_{2}$. Oxygen, $\mathrm{OH}$. Hydroxylation, FIH. Factor inhibiting HIF, VHL. Von hippel lindau, Ub. Ubiquitination, p300. HIF1 $\alpha$ co activator, CBP. CREB binding protein. Downloaded and modified with permission from ${ }^{63}$.

\section{VEGF family}

Vascular endothelial growth factor (VEGF) family includes VEGF-A, VEGF-B, VEGF-C, VEGF-D and placental growth factor (PLGF) ${ }^{64,65}$ (Figure 4). VEGF-A, which is normally referred as VEGF, is the classical angiogenic ligand with its receptors VEGFR2 (also known as KDR/ Flk1) and VEGFR1 (FIt-1) ${ }^{65,66}$. VEGF-C and VEGF-D has binding capabilities towards VEGFR2 and VEGFR3 (FIt4) ${ }^{65}$. VEGFR1 has a binding capacity for VEGF-B and PLGF. VEGFR2 is also a receptor for exogenous VEGF-E and $-F^{65}$. VEGF has context-specific roles and can act both as an angiogenic or anti-angiogenic factor because it is expressed both in newly formed vessels and in the preexisting, quiescent vessels ${ }^{66}$. In addition the binding capabilities of VEGF ligands to different receptors at the same time could explain pervasive functions as either pro and antiangiogenic ${ }^{65}$. VEGF ligands and their receptors are very dynamic in nature for example classical VEGF-A, has important roles both in the development and in pathology. It has different molecular subtypes, these are VEGF-A 121, VEGF-A 145, VEGF-A 165, VEGF-A 189, VEGF-A $206{ }^{67}$. These isoforms differ because of their difference in the binding affinity towards 
extracellular matrix molecules and their size, but are all active as dimers ${ }^{68}$. VEGF-A ${ }_{165}$ is a highly expressed isoform in human beings and exhibits moderate affinity for the co-receptor neuropilin and heparin, and hence possess moderate diffusibility. In contrast, VEGF-A 121 expression is even higher in humans and lacks the binding domain for both neuropilin and heparins ${ }^{68-70}$ which helps to easily diffuse. While VEGF-A 189, VEGF-A 206 are poorly expressed and possess higher affinity and binding capabilities for heparin, which leads to less diffusibility and accumulation in the extracellular matrix ${ }^{68}$. Not only the ligands, but their receptors also have a prime role in both normal development and a pathological condition. In a mouse embryo, studies have shown that both VEGFR1 and VEGFR2 are important for normal development of the blood vessels ${ }^{67}$. VEGF family has important roles in pathological conditions because several studies have demonstrated the presence of VEGF in tumors, AMD or DR ${ }^{67}$. VEGF-A is believed to be the main angiogenic ligand in AMD and therefore it is well studied and still under investigation for its destructive nature in the disease progression ${ }^{69}$. VEGFs have different binding affinities for their respective receptors for example the binding affinity is higher between VEGF and VEGFR1 and is lower between VEGF with VEGFR2. However, the signaling capacity is much higher through VEGF-R2, and VEGF-R2 is the prime receptor for evoking a migratory and proliferative phenotype. This means that the angiogenic response begins when VEGF has reached a level where it starts binding to VEGFR2. In contrast VEGFR3 have higher affinity for its specific ligands VEGF-C and VEGF-D ${ }^{68}$. Detailed in Figure 4.

VEGF family receptors works as tyrosine kinases ${ }^{71,72}$. Endothelial cells express the receptors VEGFR1, VEGFR2 and VEGFR3 (in the case of growing or lymphatic endothelial cells) while other cells such as neutrophils, monocytes, macrophages, progenitor cells and mural cells express VEGFR1. In the retina, however, retinal ganglion cells express VEGFR2. The affinity of PLGF and VEGF-B towards VEGFR1 is higher but still their role for angiogenesis whether developmental or physiological in the adult is unclear and require further studies. ${ }^{73}$. On the other hand VEGFR3 has higher affinity for their ligands VEGF-C and -D. VEGFR3 are found to be expressed on the lymphatic endothelial cells with their main role being lymphangiogensis 72. Developmental and tumor angiogenesis is still dependent on VEGFR3 signaling in the adults 74-76. 


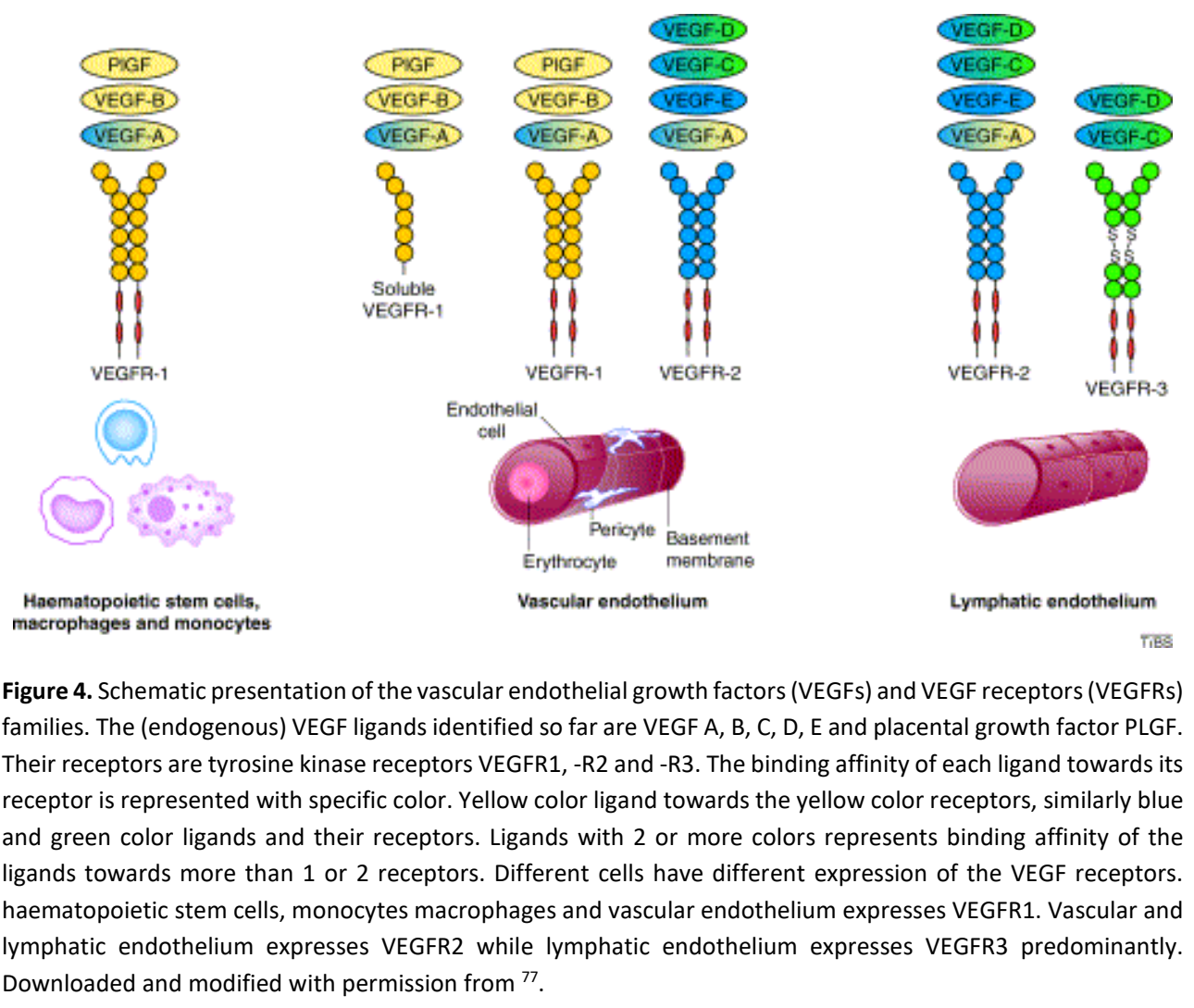

\section{VEGF signaling in CNV}

VEGF is one of the most important factors necessary for the development of blood vessels. It is present and produced during both normal developmental angiogenesis and in pathological conditions such as $C N V$ associated with $A M D{ }^{67,78}$. VEGF is found in the neovascularized tissues of patients with wet AMD which indicates engrossment in CNV ${ }^{79}$. Overexpression of VEGF leads to the development of pathological vessel formation across the Bruch's membrane into the retina which will ultimately results in the loss of vision as described above ${ }^{80}$. Classical signaling occurs when VEGF binds to their receptors. However, VEGF binding to VEGFR2 leads to a cascade of events through phosphorylation of the receptor and activating endothelial cells for proliferation, or cell migration whereas signaling through VEGFR1 mainly leads to endothelial cell survival signaling. Downstream signaling pathways mainly involve for example

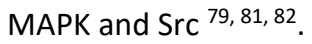

VEGFR1 and -R2 are expressed mainly in the endothelial cells with few exceptions. VEGFR1 is expressed in trophoblast cells ${ }^{83}$ renal mesangial cells ${ }^{84}$ and monocytes ${ }^{85}$. While VEGFR2 is expressed in the retinal progenitor cells, hematopoietic stem cells and megakaryocytes ${ }^{86,87}$. Hypoxia has an effect on the transcription of VEGFR1 and VEGFR2, slightly less effect than that on VEGF though. Hypoxia leads to an increase the transcription of VEGFR1 more than VEGFR2 
88 as hypoxia can also overexpress and/or stabilize VEGFR2 with a mechanism that could be mainly posttranscriptional ${ }^{89}$. This could be because VEGF regulates the production of VEGFR1 and VEGFR2 under hypoxia ${ }^{90,91}$. Interestingly, in cells, binding VEGF to the receptor VEGFR1 mainly lead to cell survival and not cell proliferation while binding of VEGF to the receptor VEGFR2 initiates cell fenestration, proliferation and migration ${ }^{92,}{ }^{93}$. There is a definite difference between the signaling pathways induced through VEGFR1 and VEGFR2 activation, but it is not well known yet. One of the possible reasons for VEGF-VEGFR1 as not initiating the cell proliferation could be that this signaling does not activates MAPK signaling pathways ${ }^{85,94-}$ 96.

\section{VEGF as a target for CNV}

VEGF is one of the most potent growth factor responsible for CNV and drives progression to wet $A M D$, but other proteins could also be involved in this complication ${ }^{97-106}$. VEGF is highly expressed in a mouse laser CNV model ${ }^{107}$. Blocking VEGF or their receptors could reduce the pathological vessels formation. Anti-VEGF drugs are currently the first line treatment strategy for CNV due to wet AMD ${ }^{108}$. A large number of patients are, however, still non-responsive to anti-VEGF treatments, or develop resistance over time ${ }^{109-111}$.

The mode of administration of these drugs is local, which means patients have to be locally administered into the eye ${ }^{112}$ requiring the need of highly trained medical doctors and specialists to perform these injections directly into the eye. The overall burden in terms of logistics increases in the form of expenses, work-load on the retinal specialists and transport as the patients need to go to larger cities hosting central hospitals to get these treatments. Furthermore the treatments are associated with a low, but potentially detrimental side effect known as endophthalmitis; infections inside the eye which could lead to blindness in its own right. As these drugs are administered often once a month and often for decades, the number of injections means that, the accumulated risk per individual is significant. Therefore, it is important for the development of more drugs and new ways for an easy administration of the current drugs.

\section{NF-KB signaling in zebrafish}

NF-KB is an important transcription factor for inflammatory signaling pathway involved in processes such as angiogenesis, inflammation, autoimmune diseases (Figure 5). 5 genes build up NF-kB transcription factors family. These genes are NF-kB1, NF-kB2, Rel-A, c-Rel and Rel B with their respective proteins: P50, P52, P65, REL and RELB respectively ${ }^{113}$. A homology domain is common between all these proteins, which is known as Rel homology domain (RHD) responsible for DNA binding, dimerization and interaction with various inhibitors. 2 different types of proteins are coupled with NF-KB; Rel-A and P52 ${ }^{114}$.

Due to the presence of IkBs, which are the inhibitors of NF-KB in the cytoplasm, NF-KB remains inactive transcriptionally. IkBs are a family of proteins made of $\mathrm{lkB} \alpha, \mathrm{lkB} \beta, \mathrm{lkB} \gamma(\mathrm{NEMO})$, IkBE and $\mathrm{Bcl}-3$ coupled to ankyrin and interacting with NF-KB via RDH domain in such a way keeping $N F-k B$ in the cytoplasm in the inactive form ${ }^{114}$. Phosphorylation of $I k B \alpha, I k B \beta, I k B \varepsilon$ leads to the release of NF-KB, which is then free to diffuse to the nucleus and activate transcription. 
This phosphorylation is catalyzed by IKKs, which is a complex, constituted of IKK $\alpha$ (IKK1) and IKK $\beta$ (IKK2) and another regulatory factor IKK $\psi$. There are several upstream activators, which could be responsible for activation of the NF-KB signaling pathway. These include cytokines, growth factors, tyrosine kinases, certain growth factor receptors such as epidermal growth factor receptors, insulin growth factor receptors and tumor necrosis growth factor receptor. In addition to these activation factors other signaling pathways such as RAS/MAPK, PI3/AKT could also be responsible for the activation of NF-KB signaling cascade ${ }^{114}$.

The activation of the NF-kB is via 2 different pathways classical, also known as canonical pathway and alternative also known as non-canonical pathway ${ }^{115}$. The canonical activation of NF-KB yields RelA and P50 with translocation of these subunits into the nucleus after degradation of IkBa subunit mediated by IKK. This process is a result of phosphorylation of the complex by IKK ${ }^{116,117}$. While non-canonical NF-KB activation, yields into RelB and P52 utilizing the $\mathrm{p} 100$. This method of activation has advantages over the classical pathway because the non-canonical pathway is involved in several therapeutic implications such as lymphoid system development, dentritic activation and metabolism in the bone ${ }^{118}$.

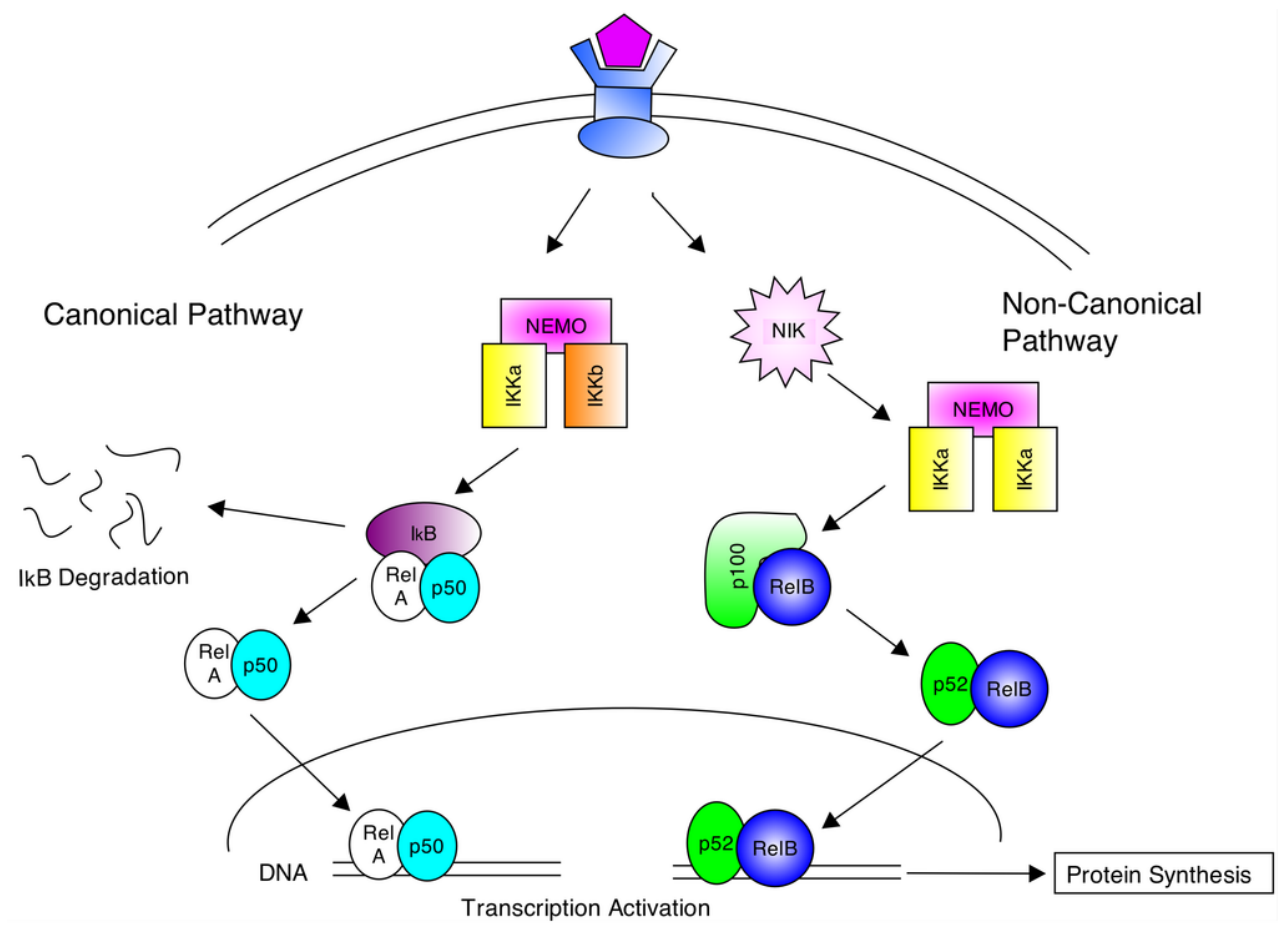

Figure 5. NF-kB signaling pathway can be activated by external stimuli, leading to either the canonical or the noncanonical pathway activation. IKK complex degrades upon the activation of both the pathways the inhibitory IkB (canonical pathway) or p100 (non-canonical pathway), which will lead to the active factors RelA/p50 (canonical pathway) or RelB/p52 (non-canonical pathway) being translocated to the nucleus to regulate the transcription of the proteins. NIK. NF-KB-inducing kinase. Downloaded and modified with permission from ${ }^{119}$. 


\section{Zebrafish as a biological model}

Over the past two decades, zebrafish has emerged as a very popular animal model in the biomedical research ${ }^{120}$. It has numerous advantages over other vertebrates for example, they are transparent, very fast growing, robust, requires minimal space for breeding and maintenance ${ }^{121}$. Zebrafish develop externally, they have high fecundity, and they are amenable to pharmacologic and genetic studies ${ }^{122}$. Zebrafish has the ability to develop faster. The maintenance cost is less than $1 \%$ for zebrafish as compared to mice ${ }^{123}$. Zebrafish has advantages over other vertebrate model systems, such as their developmental speed can be controlled over time with the temperature, by keeping them at room temperature their development can be delayed ${ }^{124}$. Genetic manipulation and the development of new genetic tools such as morpholinos and the Cas9/CRISPR technology made zebrafish a suitable model to understand molecular factors important for many human diseases such as cardiovascular-, neurodegenerative-, infection-, cancer-, and developmental biology ${ }^{125}$. In addition, they also have the ability to regenerate for example they can even regenerate their own heart if a piece has been cut off 126127 .

Zebrafish development outside the fetus makes it an exceptionally important model organism for studying eye diseases. One can observe all aspects related to the development of the eyes from once they appear. Similarities between the eye anatomy of zebrafish and humans makes it a very useful model system for studying eye diseases ${ }^{128}$. Development of specific disease models such as for studying DR ${ }^{129}$ led the foundation for understanding mechanism behind these disease.

The tumor xenograft model of zebrafish is a very useful tool for studying cancer biology ${ }^{130}$, 131. Zebrafish embryos which develops outside the uterus and its transparent nature makes it an optimal animal mode for studying the dissemination and metastases of tumor cells ${ }^{132}$. Zebrafish is used widely in understanding molecular and cellular mechanisms because the genome is fully sequenced and well annotated ${ }^{133}$. Several mutants and knockout strains have already been generated to study effects of particular genes and their involvement in diseases or if they are crucial for the development. In addition, using morpholinos, researchers can generate knockdowns of specific genes over a short period of time during initial development 134. Zebrafish can be used as a mechanistic model to investigate many diseases such as neurobehavioral disorders ${ }^{135}, 136$. Furthermore, development and signal transduction controlled by the signaling pathways are very much similar to that in human beings ${ }^{137}$.

\section{Zebrafish tumor xenograft model}

Cancer is not a single factor disease; it is a combination of many factors and events, which enables a series of events leading to tumor growth and metastatic dissemination. Factors involved in cancer are many; genetic, environmental, epigenetic modifications lead to diversity of the disease ${ }^{138-140}$. In order to identify new clinical targets of such diverse disease mechanisms, thorough investigation of the pre-clinical data obtained from the different animal models are needed ${ }^{141}$. 
Tumor metastasis has been studied with a variety of animal models including chick embryos and mouse ${ }^{142}$. On the other hand, zebrafish provides a unique animal model for studying tumor metastasis, growth and angiogenesis associated with the tumors ${ }^{143-146}$ (Figure 6). This vertebrate animal model provides ease in all aspects throughout the procedure. From handling to a complete experiment, zebrafish provides a variety of advantages over other traditional animal models. Not only the transparency, which enable continuous visualization and data collection from the same embryo over time, but also genetic modifications within the zebrafish host or the tumor cells is very easy ${ }^{147}$. Zebrafish also provide a whole circulatory system from early stages of embryonic development which make them an even better model system for studying the biology of tumor vessels and the process of hematogenous metastasis 148 .

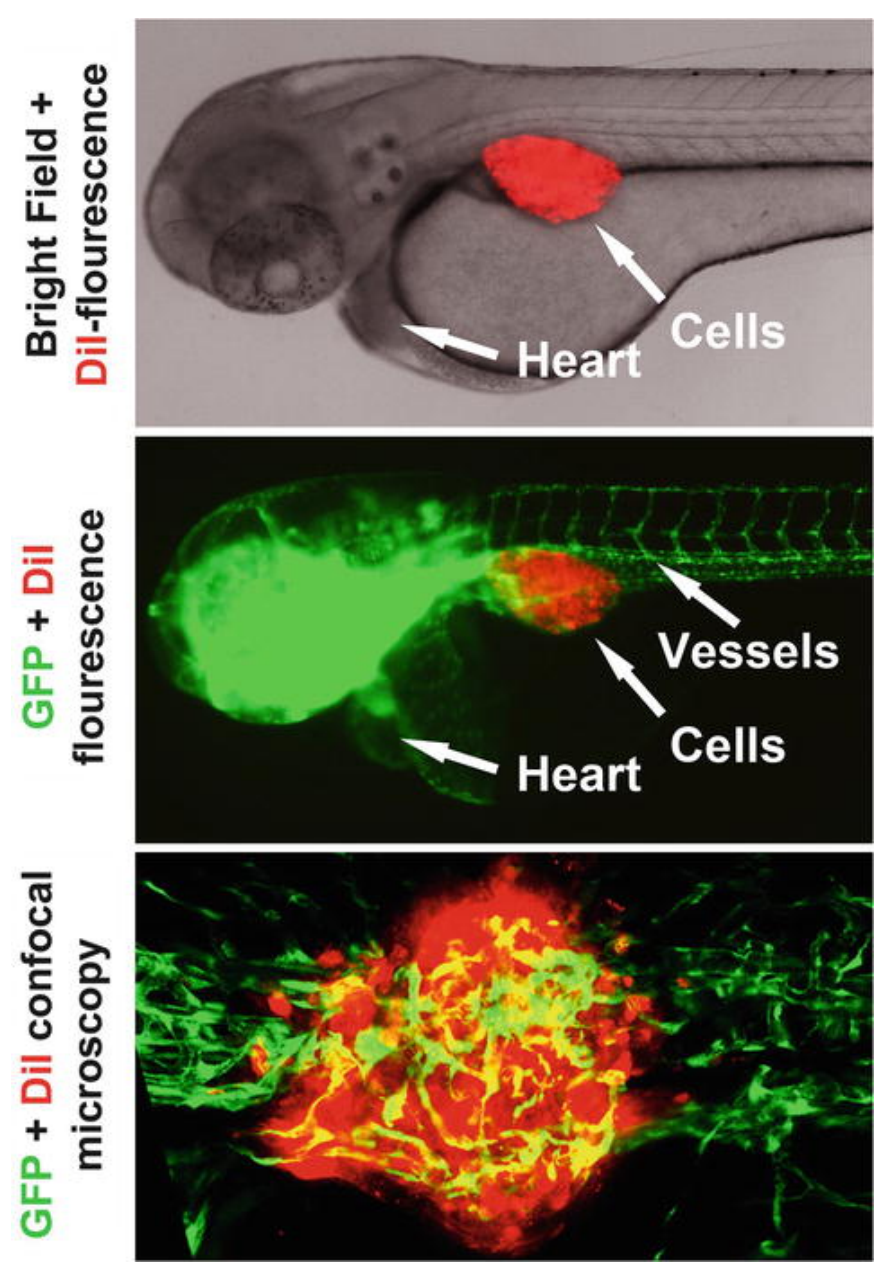

Figure 6. Zebrafish tumor xenograft model. Dil labelled tumor cells (red) were injected in the peri-vitteline space (PVS) of the Tg(fli1a:EGFP) endothelial reporter zebrafish strain (vessels shown in green). Cells were injected only in the PVS, which can be followed after injection to see the tumor growth within the proximity and see dissemination of the cells over the whole body. Downloaded and modified with permission from ${ }^{149}$. 


\section{Biomaterials as drug delivery polymers}

With the advances in technology, there is need for improvement in treating diseases in a most affordable and convenient manner for the patients. Conventional pharmaceutical formulations are rapidly diminishing in favor of new technological vehicles such as modern biomaterials ${ }^{150}$. Biomaterials are highly contributing to the health care system and are used in over 40,000 different pharmaceutical preparations today. The need for biocompatible polymers emerged because of the development of large molecular weight drugs. These drugs were very difficult to deliver to the right tissue as they were degraded by enzymatic reactions if taken orally or destroyed by the body if administered Intramuscularly ${ }^{151}$. With the use of biomaterials different important pharmacodynamics and pharmacokinetic aspects have been controlled and improved for example delivery of large molecular weight drugs to restricted locations where it was originally difficult to reach with large molecular weight drugs, and controlled delivery of drugs over time ${ }^{151}$. 


\section{Aims}

This thesis set out to investigate angiogenesis in development and in disease, using the zebrafish model.

\section{General aim}

The overall aim of this thesis was to use zebrafish animal model to understand factors, important for hypoxia- or NF-kB-induced pathological angiogenesis, developmental angiogenesis, and to use zebrafish as a tool for understanding tumor progression and to develop biomaterials as drug delivery polymers.

\section{Specific objectives}

- To investigate mechanisms behind hypoxia-induced neovascularization in the adult zebrafish choroid, to mimic AMD. (Paper I).

- To understand development of choroid blood vessels in zebrafish embryos. (Paper II).

- To study the biology of the inflammatory pathway NF-kB, the signaling networks involved and effects on inflammatory responses on angiogenesis in general and specifically in the eye (Paper III).

- To use zebrafish as a tool for understanding complex mechanism behind tumor cell disseminations and to use zebrafish as a model to study new angiogenic drug delivery vehicles based on hydrogels (paper IV and V). 


\section{MATERIALS AND METHODS}

\section{Zebrafish strains}

Transgenic zebrafish strains used in this thesis were obtained from ZIRC Oregon ${ }^{152-157}$, Affolter lab 158, 159, 160, 161 and Stainier lab 162, 163, 164. Table 1 summarizes the reporter strains and the

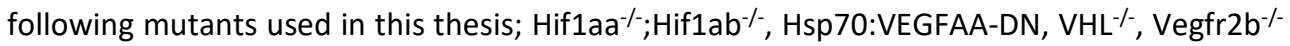
$\left(\mathrm{kdr}^{-/-}\right), \operatorname{Vegfr}^{-\mathrm{a}^{-/-}}\left(\mathrm{kdrl}^{-/-}\right)$.

Table 1. List of zebrafish strains used in Papers I-V.

\begin{tabular}{|l|l|l|}
\hline Strain & Labelled cells & Fluorophore \\
\hline Tg(fli1a:EGFP)y1 & Endothelial cells & Green \\
\hline $\operatorname{Tg}($ kdrl:DsRed2)pd27 & Endothelial cells & Red \\
\hline Tg(kdrl:EGFP)s843 & Endothelial cells & Green \\
\hline Tg(acta2:EGFP)ca7 & Smooth muscle cells & Green \\
\hline Tg(tagln:EGFP)p151 & Smooth muscle cells & Green \\
\hline Tg(fli1ep:Gal4FF;UAS:RFP) & Endothelial cells & Red \\
\hline Tg(gata1a:DsRed2)sd2 & Erythrocytes & Red \\
\hline Tg(pdgfrb:mcitrine;kdrl:DsRed2) & Pericytes & Green+Red \\
\hline $\begin{array}{l}\text { Tg(fli1ep:Gal4FF;UAS:VE- - } \\
\text { EGFP)ubs12 }\end{array}$ & $\begin{array}{l}\text { Adherence junctions in } \\
\text { Tg(fli1ep:Gal4FF;UAS:EGFP- } \\
\text { ZO.1)ubs5 }\end{array}$ & Green \\
\hline $\begin{array}{l}\text { Tg(fli1ep:Gal4FF;UAS:EGFP- } \\
\text { UCHD)ubs18 }\end{array}$ & F-Actin in ECs & Green \\
\hline
\end{tabular}

All the zebrafish strains were raised and maintained at Linköping University zebrafish core facility under standard protocols 165,166 . The ethics committee of Linköping University approves all the experimental procedures. Other animal models used in this thesis include mouse and rats. We have developed and used numerous assays and protocols to achieve our goals for this thesis, they are summarized in Table 2. For detailed information, please refer to Paper I-V. 
Table 2. List of analytical techniques used in Papers I-V.

\begin{tabular}{|c|c|c|c|c|c|}
\hline Technique & Paper & 2 & 3 & 4 & 5 \\
\hline Vascular leakage evaluation & $x$ & $\mathrm{X}$ & & & \\
\hline Treatment with VEGFA-dn & $\mathrm{X}$ & $\mathrm{X}$ & & & \\
\hline FACS & $x$ & & & & \\
\hline RNA- Sequencing & $\mathrm{x}$ & & & & \\
\hline Immunohistochemistry & $x$ & & $x$ & & $x$ \\
\hline qPCR & $\mathrm{X}$ & & $\mathrm{X}$ & $\mathrm{X}$ & \\
\hline Western blot & $x$ & & $x$ & $x$ & $x$ \\
\hline TEM & $\mathrm{X}$ & $\mathrm{X}$ & & & \\
\hline SEM & & & $x$ & & $x$ \\
\hline Histology & $\mathrm{X}$ & $\mathrm{X}$ & $\mathrm{x}$ & $x$ & $x$ \\
\hline Cell culturing & & & $x$ & $x$ & $x$ \\
\hline Cell migration/ Tube formation assay & & & $\mathrm{x}$ & $\mathrm{x}$ & $x$ \\
\hline Whole mount assay & $x$ & $x$ & & & \\
\hline Microarray analysis & & & & $x$ & \\
\hline Zebrafish tumor dissemination assay & & & & $x$ & $x$ \\
\hline Elisa & & & & $x$ & $x$ \\
\hline
\end{tabular}

\section{Hypoxia treatment}

As previously described ${ }^{49}$, 167-169 experimental fish were subjected to hypoxia in a custom made chamber (Figure 7), for 10 days at $10 \%$ of the normal air oxygen. The tank was sealed in order to block oxygen leakage into the water. The concentration of oxygen in water was controlled by an electrode (Figure 7/2) dipped in water near a rotating stirrer (Figure 7/1), which keeps a homogeneous level of oxygen in the water. An air-stone (Figure 7/3) was placed at a corner with nitrogen gas perfusion to reduce or control the oxygen concentration in the tank. A valve (Figure 7/5) operated via an oxygen control device (Figure $7 / 4$ ), control gasperfusion in an automated way when the water oxygen concentration increased beyond a preset value (i.e. $10 \%)$. 


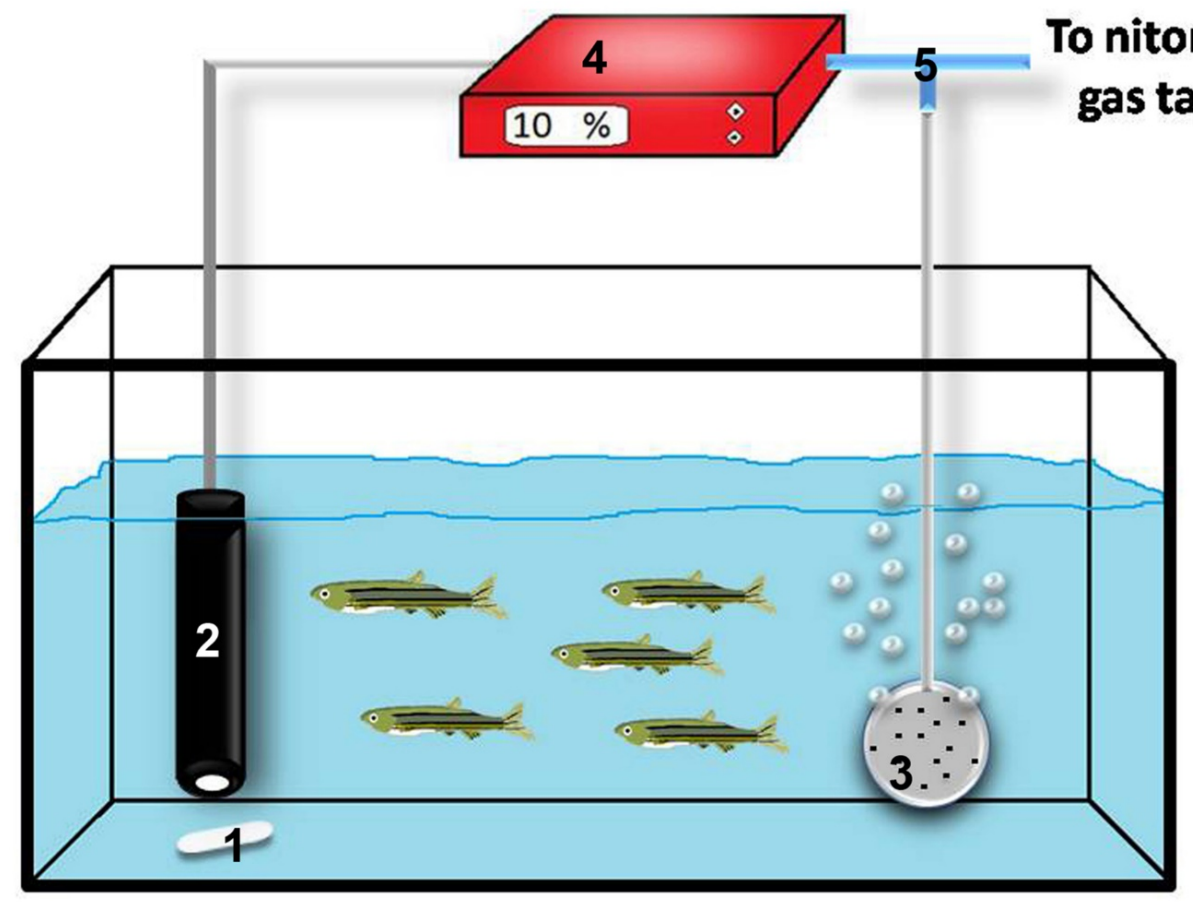

Figure 7. Hypoxia setup for adult zebrafish. 1. Magnetic stirrer, 2. Electrode for sensing oxygen concentration in the water, 3 . Nitrogen gas perfusing stone, 4 . Controller device, 5 . Valve connection between nitrogen gas and the tank. Downloaded and modified with permission from ${ }^{170}$.

\section{Hypoxia treatment with Vegfaa-DN and DMH4}

Vegfaa-DN zebrafish were treated at $37{ }^{\circ} \mathrm{C}$ daily for 1 hour to induce high-level expression of dominant-negative VEGF-A between the $4^{\text {th }}$ and the $10^{\text {th }}$ day of exposure to hypoxia. For DMH4treatment experiment the fish have been subjected to water containing the final concentration of $1 \mu \mathrm{M}$ of the drug.

\section{Dissection and euthanizing adult zebrafish}

Adult fli1a:EGFP zebrafish were used for identification of the CCs. After euthanizing the zebrafish with $0.04 \%$ Ethyl 3-aminobenzoate methane sulfonic acid salt 98\% (Sigma Aldrich) and fixing the adult zebrafish in PFA $4 \%$ (Sigma Aldrich) at $+4^{\circ} \mathrm{C}$ for 24 hours, their eyes were dissected to isolate the retina and choroidal tissues allowing visualization of the retinal vessels (RVs), choriocapillaries (CCs) and the rete mirabile (RM). The dissection procedure was inspired by previously published methods, although with some modifications ${ }^{168,171}$. In this work, dissections were done with the help of a spring scissor and Dumont \# 5 tweezer. The critical step in the dissection of the adult zebrafish eye is that sometimes the retinal vessels peel off while removing the lens from the eye. It is important to first make a hole from one side of the eyecup holding the fish in a posterior position with one hand and use another hand for making the hole. Once a hole was made at one edge of the eye, I have prolonged the cut 
on each side using spring scissors starting from that first hole made. Until half of the cornea is detached the remaining half still attached. With the spring scissor the cornea was cut off in 2 halves, then the lens was removed by using the spring scissor with its edges (scissor) open in the vitreous, holding and pushing the lens out. This will keep the retinal vessels attached to the retinal surface. Later, the cornea should been peeled off on both sides leaving an open intact eyecup. The eyecup along with the sclera was pulled out from the head using Dumont \# 5 tweezer with good care. The detached eyecup is moved to the dish in PBS where the sclera was peeled off slowly and gradually, by cutting small pieces at first so that the RM and CCs remain intact. Sometimes the optic artery detaches with the eyecup, if so, it is important to cut it off to facilitate removal of the sclera. Once the whole sclera is removed, the RM can be removed carefully such that it does not detach any piece from the CCs. After removal of the $\mathrm{RM}$, the CCs can be peeled off from all the corners slowly and with a lot care because of the extremely delicate nature of this tissue. Once all the tissues have been set apart, the retina cup can be cut in 4-5 radial cuts so that they can be flat mounted in a flower like structure on the glass slide using a stereomicroscope (Nikon SMZ 1500). The same was repeated for the $\mathrm{CCs}$ and mounted on the glass slide. The RM has been mounted the way they are without any cuts. Vectashield (H-1000 Vector laboratories) was used to protect the tissues from drying and to improve image quality when they were flat mounted. In addition, few drops of nail polish was used on the edges of the glass slides, which will help the tissues to hold tight.

\section{Vascular leakiness evaluation in the choriocapillaris}

Vascular leakiness was evaluated in both the embryos and the adult fli1a:EGFP zebrafish according to the standard protocol ${ }^{172}$. Adult zebrafish were anesthetized with $0.02 \%$ Ethyl 3 aminobenzoate methane sulfonic acid salt 98\% (Sigma Aldrich) followed by i.p injection of rhodamine labeled lysine conjugated dextran and transferred to normoxia for 15 minutes. Later they have been euthanized and fixed in $4 \%$ PFA for $24 \mathrm{~h}$ at $+4{ }^{\circ} \mathrm{C}$. CCs was dissected, flat mounted and visualized as described above. Fli1a:EGFP embryos with varying ages of 48 $120 \mathrm{hpf}$ were anesthetized with $0.02 \%$ Ethyl 3-aminobenzoate methane sulfonic acid salt $98 \%$ (Sigma Aldrich) on a 2\% agarose plate following 2-4 $\mathrm{nl}$ injection of $70 \mathrm{kDa}$ rhodamine labeled lysine conjugated dextran in common cardinal vein (CCV) (Figure 8). The embryos were transferred in the E3 medium and left for 15 minutes. The embryos were anesthetized and euthanized with a lethal dose of $0.08 \%$ Ethyl 3-aminobenzoate methane sulfonic acid salt $98 \%$ (Sigma Aldrich) and fixed in 4\% PFA for 30 minutes at room temperature. The eyes have been dissected out and flat mounted on the glass slide using watchmakers' forceps (Dumont \#5) under a dissection stereo-microscope (Nikon SMZ 1500) in a mounting medium Vectasheild $(\mathrm{H}-$ 1000 Vector laboratories). 


\section{Agarose plate Anesthetized embryos}
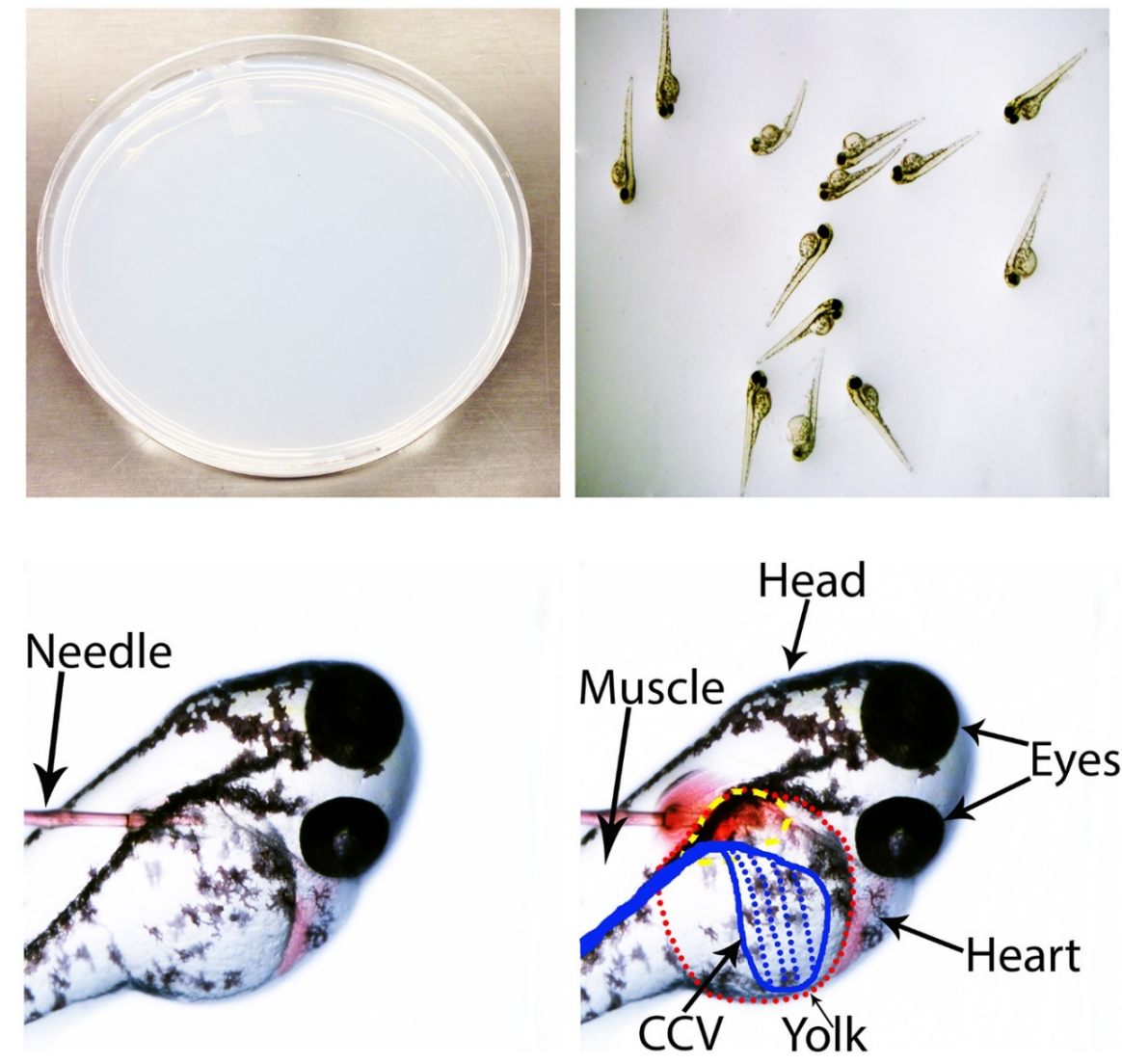

Figure 8. Evaluation of leakage in the zebrafish embryo CCs. 2dpf zebrafish embryos anesthetized on $2 \%$ agarose plate. A model used for injecting tumor cells in the peri-vitteline space (PVS) in the area marked by the yellow dotted line and for injecting rhodamine labeled dextran in common cardinal vein (CCV). Downloaded and modified with permission from ${ }^{149}$.

\section{Time lapse video analysis}

Fli1a:EGFP zebrafish embryos at different ages were mounted in a mixture of MS-222 (Ethyl 3-aminobenzoate methane sulfonic acid salt 98\%, Sigma Aldrich) $25 \mu \mathrm{g} / \mathrm{ml}$ and $0.5 \%$ low melting agarose (Sigma Aldrich). A special petri dish with a glass bottom (MatTek Corporation) was used for mounting. It is important to keep the temperature of the agarose around $35^{\circ} \mathrm{C}$ before adding the embryos to the mixture but if it's too cold the agarose will solidify and it will be difficult to keep the embryos in the right angle and position. Care should be taken not to add more mounting agarose than required to the well as a thick layer will disturb the imaging. E3-PTU medium should be added to the rest of the dish after 5 minutes so that at first the agarose gel solidifies completely. Using a confocal microscope (LSM 700 inverted, Zeiss, USA), z-stacks of the time-lapse series have been taken at 15 or 20 minutes interval between each frame. For further analysis and videos were made with Image $J(\mathrm{NIH})$ at 10 frames per seconds (fps). 


\section{RESULTS AND DISCUSSION}

\section{Identification of pathological vessel remodeling in the choroidal vessels of adult zebrafish (Paper I)}

We have identified CCs in the zebrafish for the first time by careful dissection using the fli1a:EGFP zebrafish strain. The nature of CCs in the zebrafish amaze us in many ways, they are similar to those found in most of the mammals including humans ${ }^{173,174}$, they lie close to the retina just behind the Bruch's membrane and do not penetrate into the retina. They are very dense and constitute around $95 \%$ of the tissue as compared to the retinal vessels, which only cover around $25 \%$ in their most dense (capillary) area. Behind the CCs is a third layer of the vessels known as rete mirabile (RM) in a half moon shape (Figure 2).

Hypoxia drives neovascularization in both health and diseases ${ }^{175,176}$. In order to investigate the effects of hypoxia, fli1a:EGFP zebrafish have been subjected to $10 \%$ relative air saturation which is approximately $2 \%$ oxygen. Hypoxia in the fish tank has been achieved by the influx of nitrogen gas. The procedure has been presented earlier ${ }^{168,169,171}$. With this treatment we did not observe sprouting angiogenesis in the CCs, as expected, rather an increase in what appeared to be intussusception was evident. Interestingly, the vascular density has been increased in a 2D spatial manner without protruding through the Bruch's membrane, which is similar to that seen in the occult CNV ${ }^{177}$.

VEGF-A is induced by hypoxia and is found in a majority of the pathological conditions associated with angiogenesis ${ }^{178}$. We have tried to identify the role of VEGF-A and their receptors using double knock strain of HIF1 $\alpha$ a/HIF1 $\alpha b^{162}$, VEGF-A dominant negative strain which is heat shock inducible ${ }^{179}$, and a specific inhibitor of VEGFR2 ${ }^{180,181}$. We have found that intussusception was blocked in hypoxia using either of these three strategies. These results suggest the possible inclusion of the signaling pathway made by HIF1 $\alpha$, VEGF-A and VEGFR2. A schematic representation of the process involved in the progression of CNV in choriocapillaris in the presence of hypoxia is shown in Figure 9. 

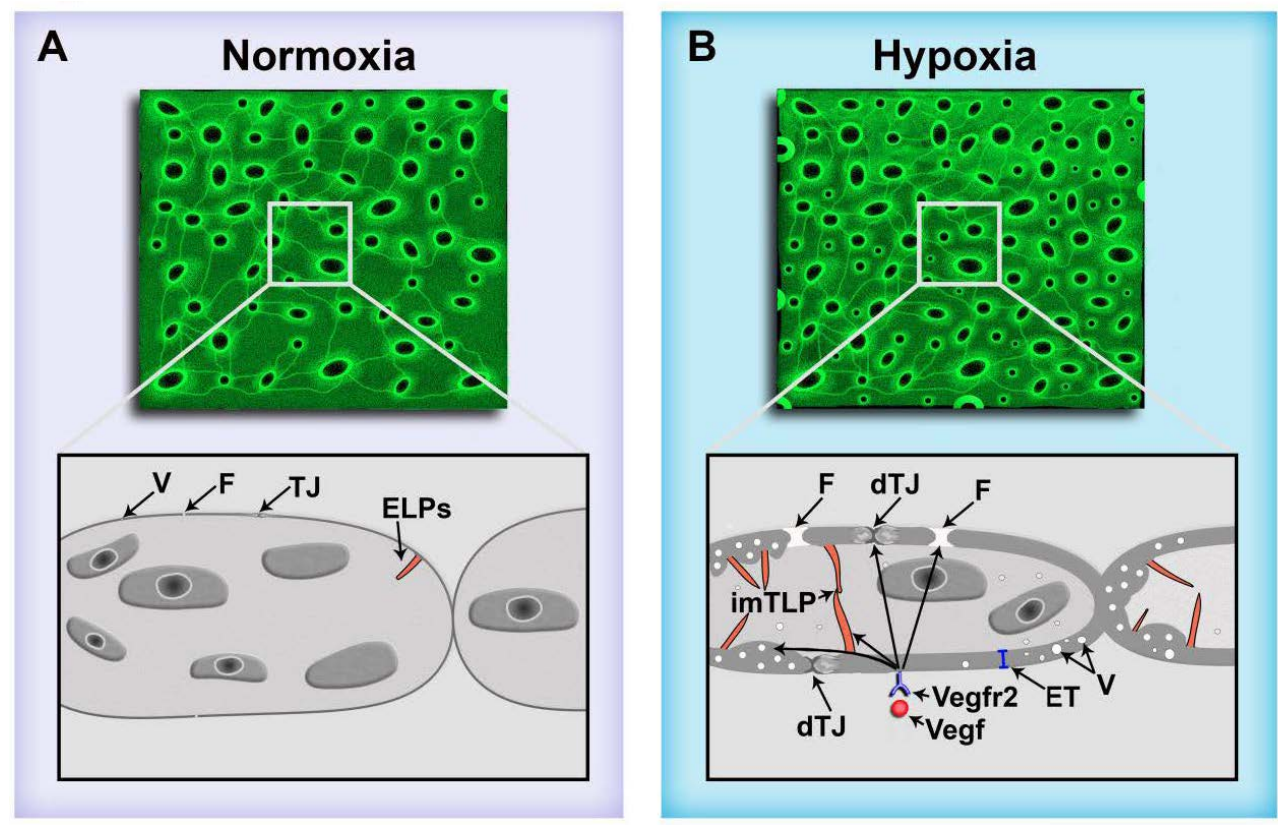

Figure 9. Schematic illustration of hypoxia induced intussusceptive angiogenesis in the CCs followed by hypoxic CNV in the zebrafish. Pillar formation following CNV involves HIF-VEGFA-VEGFR2 signaling pathways via dissolved tight junction (dTJ) enlarged fenestrations (F), immature transluminal pillars (imTLPS), enlarged endothelial thickness (ET) and endothelial vesicles (V) (Paper I).

Development of choriocapillaris occurs by vasculogenesis and sprouting angiogenesis in the zebrafish whereas the structural similarity remain the same as in mouse (Paper II)

Since choriocapillaris growth is via intussusceptive angiogenesis in the adult zebrafish, it would be very interesting to investigate the development of these vessels in the embryos. We took advantage of using the transgenic fli1a:EGFP zebrafish which expresses green fluorescence protein in the endothelial cells (ECS) ${ }^{152}$. At $18 \mathrm{hpf}$ zebrafish embryos start the development of the CCs by recruiting the ECs from the cranial division of the internal carotid artery (CrDi) and primordial midbrain channel (PMBC) (Paper II). At $24 \mathrm{hpf}$ the total eye field is populated with ECs which further leads to the formation of blood islands at $36 \mathrm{hpf}$ and further continues to mature and develop. At $48 \mathrm{hpf}$ these blood island forms connections with tube-like structures which further lumenized at $72 \mathrm{hpf}$. Interestingly, this process is synchronized throughout the eye field (Figure 10). Later at 96 and 120 hpf these vessels mature to form CCs. The whole process is explained in a schematic presentation (Figure 10). Maturity of CCs appears to happen approximately at $72 \mathrm{hpf}$ during development. With the help of intravenous injections of rhodamine labeled dextran in fli1a:EGFP we found that the CCs at $48 \mathrm{hpf}$ are not perfused rather more leaky. 


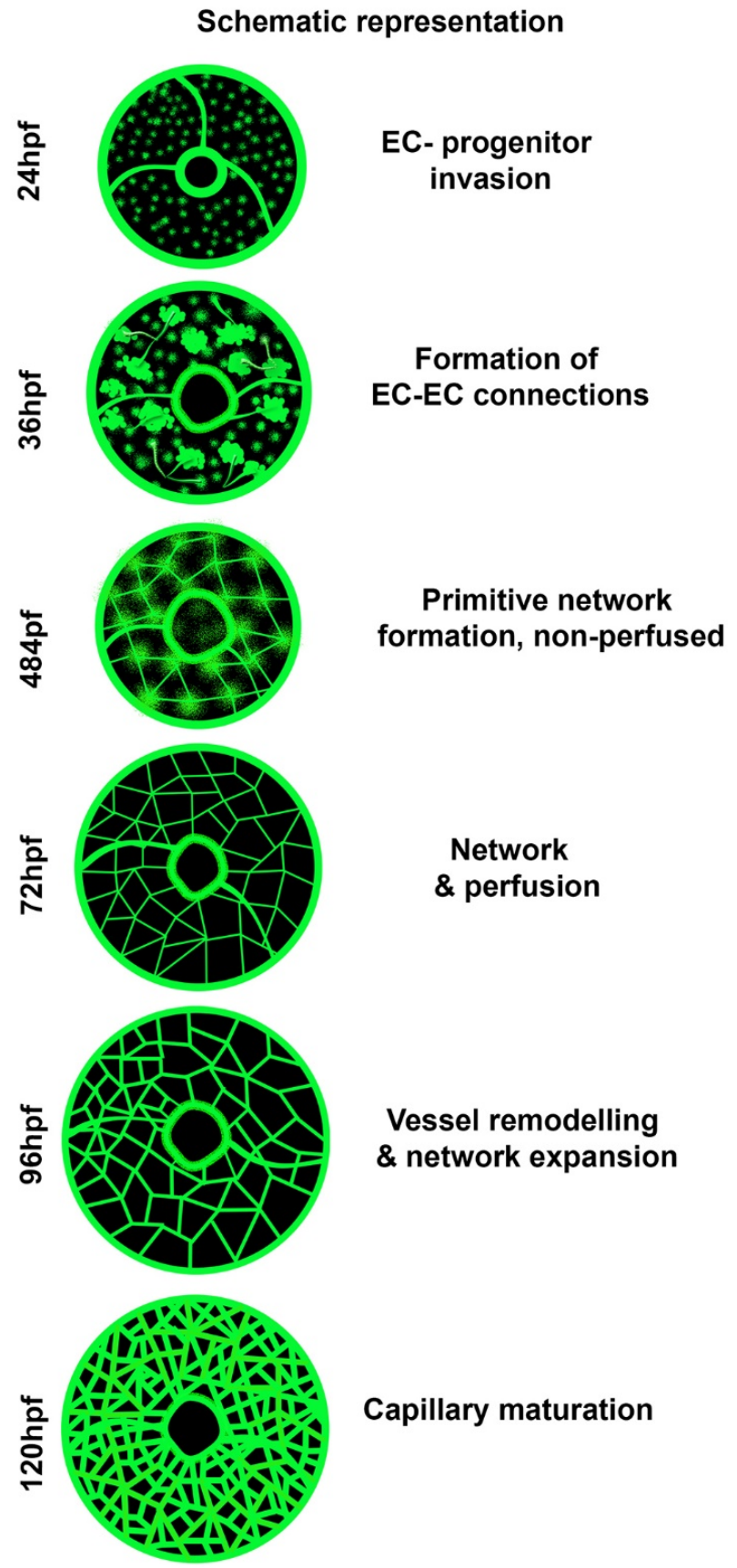

Figure 10. Schematic representation of the development of the CCs from 24-120 hpf. Choriocapillaris develops via sprouting rather than intussusceptive angiogenesis. Endothelial cells (EC) migration starts at $18 \mathrm{hpf}$ from $\mathrm{CrDi}$ and PMBC until $24 \mathrm{hpf}$ that leads to the formation of blood islands and EC-EC connections at $36 \mathrm{hpf}$. At $48 \mathrm{hpf}$ a primitive vasculature is formed which is still not perfused and non-lumenized followed by perfusion and maturation of the network at $72 \mathrm{hpf}$. At $96 \mathrm{hpf}$ vessel remodeling and expansion dominates, which ultimately leads to vascular maturation at $120 \mathrm{hpf}$ (paper II). 
We have used new strains of zebrafish to understand the involvement of the VEGF signaling pathway. During mammalian development and disease, hypoxia regulates VEGF production 182. In order to better understand the role of hypoxia regulation and its effect on the development of CCs, we have used a von Hippel-Lindau mutant $\left(\mathrm{VHL}^{-/-}\right)$zebrafish strain which have stabilized HIF1 $\alpha$ leading to increased hypoxia signaling which in contrast to HIF1 $\alpha$ mutants ( $\mathrm{HIF} 1 \alpha^{-/-}$), that lack this aspect of hypoxia signaling. CCs in $\mathrm{VHL}^{-/}$embryos show many holes and sprouts compared to WT littermates, as expected. In the CCS of HIF1 $\alpha$ mutants, however, remains the same as in control group. This suggests that VEGF is apparently upregulated in hypoxic conditions but that baseline VEGF is likely not HIF-dependent during zebrafish development. To understand the role of VEGF receptors we have used VEGFR2b (kdrI-) and VEGFR2a $\left(\mathrm{kdrl}^{-/-}\right)$mutant fish. To understand directly the role of VEGF-A we have used a dominant negative mutant strain of VEGF-A which is a heat shock protein-induced VEGFaa dominant negative mutant strain. In all these strains the development of the CCs are impaired of with the most impaired development is seen in $\mathrm{kdrl}^{-/-}$with barely a few CCs rings. This demonstrates the importance of VEGF- A in early development of CCs.

\section{Inhibiting NF-kB inflammatory pathway with a selective IKK2 blocker, IMD0354 inhibits angiogenesis (Paper III)}

IMD0354 acts as an inhibitor of the IKK2 thereby inhibiting NF-kB. It acts by inhibiting the phosphorylation of the NF-kB (P 65) and its translocation in to the nucleus. As the role of NF$\mathrm{kB}$ in endothelial cell biology is poorly studied, we analyzed the effects of IMD0354 on the endothelial cells in vitro and in vivo. Angiogenesis is affected by IMD0354 in a dose dependent manner in vitro by using on human umbilical vein endothelial cells (HUVECs). The cell migration and tube formation have been inhibited. Using an ex vivo rat aortic ring assay also inhibited the sprouting angiogenesis which further confirms the anti-angiogenic effects of IMD0354. Downregulation of VEGFA and HIF1 $\alpha$ further confirms the antiangiogenic effects via involvement of HIF1-VEGF signaling pathway.

The effect of IMD0354 has been further investigated in the HUVECs where the cytoskeleton driven F-Actin has been disrupted in a dose dependent manner. The molecular players involved in the inflammation driven process was studied using HUVECs stimulated by TNF $\alpha$. It was observed that IMD0354 reduces the expression of CCL2 and CXCL5. Furthermore cell filopodia were reduced with the IMD0354 treatment is HUVECS (Paper III).

To study the in vivo effects of IMD0354 on the retinal and intersegmental vessels (ISVs) growth and the expression of VEGF-A specifically, we have used zebrafish fli1a:EGFP embryos at 0-72 hpf. IMD0354 inhibits normal development of the retinal vessels at both 5 and $10 \mathrm{ng} / \mathrm{ml}$ concentration relative to the control situation. As expected, a dose dependent inhibition of ISVs was observed. IMD0354 at $10 \mathrm{ng} / \mathrm{ml}$ also inhibits normal development of ISVs while at 5 $\mathrm{ng} / \mathrm{ml}$ effects on ISVs were non-significant. Similarly, expression of VEGF-A was impaired significantly at $10 \mathrm{ng} / \mathrm{ml}$ while slight expression has been observed at $5 \mathrm{ng} / \mathrm{ml}$ IMD0354 on 
immunostained whole mounts embryos at $5 \mathrm{dpf}$. These findings suggest that IMD0354 by inhibiting the NF-kB downregulate VEGF-A which in turn inhibit developmental angiogenesis in the zebrafish.

Anti-inflammatory and antiangiogenic effects of IMD0354 were further investigated in a rat corneal suture model. It was observed that significantly more inflammatory cells were observed by in vivo confocal microscopy in the suture group as compared to the control group. Furthermore, reduced vasodilation of the limbus vessels and overall reduced angiogenic response in the treatment group was observed. In addition, lower expression was observed in the treated rat corneas of HIF1 $\alpha$, VEGFA, CCL2, TNF $\alpha$, CXCL5, CD45. These results were consistent with the downregulation of these factors as determined by qPCR and western blot.

\section{Understanding the interlinked connections between microphthalmia associated transcription factor (MITF) and pigment epithelium derived factor (PEDF) using tumor cell dissemination model of zebrafish (Paper IV)}

PEDF and MITF expression varies in melanoma progression. Both are expressed to a lower level in the aggressive type of melanoma whereas higher expression are common in the weakly aggressive subtype. The expression levels of MITF and PEDF was studied in different types of melanomas including naevus stage hyperplastic lesions, radial growth phase melanoma, vertical growth phase melanoma, cutaneous metastases of melanoma and visceral metastases of melanoma. Immunostainings of these melanomas reveal expression of both MITF and PEDF, of which the highest expression was in the radial growth phase melanoma. In addition, human biopsies of these melanomas confirmed a positive correlation between MITF and PEDF. Human melanoma and naevus confirms the co-localization of both MITF and PEDF significantly. Metastases of primary melanoma further confirms these findings.

The role of senescence on expression of these factors was evaluated by incorporation of the lentivirus HRASG ${ }^{12 V}$ or BRAF ${ }^{\mathrm{V} 600 \mathrm{E}}$ that reveals overexpression of both MITF and PEDF by the transformed cells. The overexpression was switched to less expression upon the senescence in the transformed melanocytes. This was further confirmed with western blot analysis where the protein levels of both MITF and PEDF have been decreased. To further unveil the regulatory powers of MITF towards PEDF, MITF was silenced by a lentivirus shRNA ${ }^{\text {mir }}$ in melanoma cells (501 mel) which highly expresses PEDF and MITF. This shows downregulation of PEDF mRNA levels which confirms direct link between both the factors.

Zebrafish can be used for a number of assays of which the tumor cell xenograft model is a very interesting model ${ }^{130},{ }^{183}$. The role of MITF and PEDF was studied in the progression of melanoma cells in this model. Dissemination of the cell line $501 \mathrm{mel}$ was studied with or without MITF and PEDF. Using zebrafish xenografting and analyzing the effects of PEDF and MITF after 3 days of implanting the 501 mel cells, we have found that silencing of MITF (501mel GFP-shMITF) made the cells disseminate the most, but that the non-metastatic phenotype could be rescued by over-expression of PEDF (501mel-PEDF-shMITF) (Paper IV). 


\section{Alginate and collagen hydrogels provide a reliable therapeutic alternative for drugs and cells delivery (Paper V)}

Biocompatible polymers for drug delivery system needs validation and optimum concentration. The degradability is important for the release of the therapeutic agent(s) imbedded in these hydrogels. As collagen is readily degradable compared to alginate, we hypothesized that release of therapeutic agents could be regulated by adjusting the relative amounts of these polymers in the final product. In order to understand the right concentration of both alginate and collagen, out of 2:1, 1:1 and 1:2 of alginate:collagen respectively, we found that 2:1 was relatively stable as compared to 1:2 which degraded right away even after the first day at physiological conditions (PBS at $37^{\circ} \mathrm{C}$ ). 1:1 concentration was a perfect combination because of lower degradation properties also it was not excessively stable since degradation is obviously required for delivery of the embedded factor(s). Now to test the pharmacokinetic properties of these hydrogels, we embed them with FGF-2 producing k-1000 cells and follow the release kinetics in the scaffolds. This observation was further confirmed with ELISA where FGF-2 production was observed in the medium; higher FGF-2 release was observed at $5^{\text {th }}$ day. Similarly, hydrogels with FGF-2 led to porcine aortic endothelial cells (PAECs) being converted into tube like structures. Labeled PAECs with a red florescent dye (Dil) also confirmed the increased proliferation with FGF-2 in the hydrogel scaffold between 2-5 days as compared to the control non-FGF-2 hydrogel group.

Round shaped spheres of hydrogels were prepared, which is advantageous because they can easily be transferred to tissues by percutaneous catheters used in the thorasic surgery clinically as compared to the highly viscous materials themselves. These microspheres were prepared with the help of air-nozzle jet system where the alginate:collagen mixture were passed through a pressure syringe (Figure 11). The mixture is further cross linked with calcium. Stability of these spheres was tested for up to 6 days at $37^{\circ} \mathrm{C}$ where the cells encapsulated were fine and show moderate degradation properties, which is the ultimate goal in treating patients with ischemic problems (Paper V).

Furthermore, the biocompatibility of the alginate:collagen mixture was demonstrated in vivo using a C57/B16 mouse model. For 5 days, the implanted microspheres survived subcutaneously in the mouse. The plaques and the surrounded tissues were investigated with macrophage marker F4/80, neutrophil marker Ly6g and found that no inflammation was detected in the plaques. In order to confirm that FGF-2, at a concentration released during degradation of the microspheres could induce angiogenesis in vivo, $2 \mathrm{dpf}$ zebrafish embryos were injected with PBS or FGF-2 and the concentrations released by the microspheres reveal that FGF-2 is driving angiogenesis. Similarly, in order to confirm the role of therapeutic cells that could be delivered using these biomaterials in vivo, we have injected 3T3-Ras which are non-FGF-2 releasing fibroblast as compared to Dil labeled FGF-2 releasing K1000 tumor cells. It is evident that the vascular density was several folds increased in the masses formed by K1000 compared to 3T3-Ras cells. Finally, we want to confirm the in vivo coupling of therapeutic endothelial cells with the host vasculature in the zebrafish model. That was achieved by injecting PAECs with or without FGF-2. This assay suggests that cells with angiogenic factors such as FGF-2 couple to the host vasculature with higher efficiency 
compared to injecting these cells alone. Such approaches can be used in patients suffering with $\mathrm{MI}$, where the need is to supply such growth factors and cells, which can overcome the infarct area of the heart.

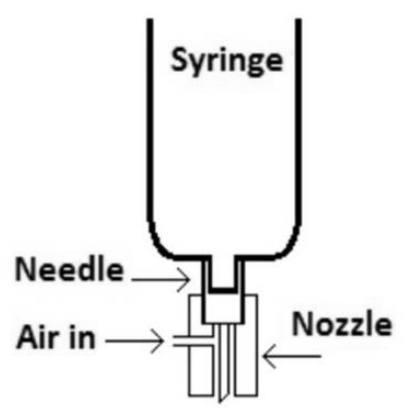

Figure 11. Schematic representation of the injector system used for the preparation of microspheres. Downloaded and modified with permission from ${ }^{184}$. 


\section{DISCUSSION}

Despite the involvement of angiogenesis in health and disease, this process is still poorly understood. In pathology, angiogenesis is a hallmark of diseases such as cancer, AMD, DR and corneal neovascularization. Over the years, numerous animal models have been developed to investigate pathological angiogenesis; however, the majority of these models does not accurately mimic the pathophysiology of angiogenesis in human diseases, for example in occult CNV or proliferative DR. In this thesis, the zebrafish model, was used extensively to study angiogenesis in the development of the choriocapillaris (Paper II), as a model for pathological angiogenesis in the adult choroid (Paper I), as a model to understand the role of NF-kB signaling in angiogenesis (Paper III), investigate the manner of tumor cell metastasis through the vasculature (Paper IV) and to investigate the efficacy of biomaterials as a means for pro-angiogenic drug delivery (Paper V).

Zebrafish is an excellent model system for studying various eye diseases ${ }^{128,185}$. By identifying CCs and RM in the adult and in the developing embryos, it will be very beneficial to study these debilitating diseases such as AMD, DR and ROP. Several advantages are associated with zebrafish, not only the ease of working with the animal ${ }^{186}$ but also the close physiological relationship of the blood vessels with other mammals including humans ${ }^{128,187}$. The structural similarity of zebrafish choroid to other mammals including humans and the cone-rich nature of the zebrafish retina (similar to humans whereas mice retinae are cone-deficient) makes it a perfect animal model, especially for studies into wet $A M D^{80,174}$.

Since a large number of patients are suffering from wet AMD especially the type associated with occult CNV, zebrafish could be a very beneficial model for studying the molecular pathways underlying progression to occult CNV. An animal model, which can rightly recapitulate the onset of neovascularization in diseases such AMD, DR or tumor related angiogenesis would be of great importance. Based on all above facts, we think that zebrafish could meet this challenge. Interestingly, in the zebrafish, we did not find evidence for sprouting angiogenesis during hypoxia-induced CC remodeling/occult CNV, which is the case in retinal vessels in the zebrafish ${ }^{71,168}$. Rather, we found that CCs remodeling during hypoxia is via interstitial pillar formation. TEM analysis of these pillars and the surrounding vasculature suggests loose tight-junctions and loose connections of the smooth muscle cells to the endothelial cells. As previously described endothelial luminal processes (ELPs) which may take the form of "labyrinth-like" vessels in patients of CNV related wet AMD ${ }^{188}$, are also present in the zebrafish. This suggests that intussuception is likely the process in the human patients for the early expansion of CCs.

VEGF-VEGFR signaling is the most well studied ligands and their receptors. Interestingly VEGF$B$, via neuropilin1 is important for the retinal vascular development and VEGF-A via VEGFR2 was shown in this thesis to be important for the normal development of CCs during developmental angiogenesis (Paper II). Blocking VEGFR2 (with relatively specific drug DMH4), significantly blocks angiogenesis in the adult CCs, which confirms the pivotal role of VEGFVEGFR signaling in this process. On the other hand, in a knockout strain for HIF1 $\alpha$ we observed 
complete lack of pillar formation in response to hypoxia, suggesting the involvement and coupling of HIF1 $\alpha$ in the signaling cascade (Paper I). AMD patients with CCs remodeling and angiogenesis are sometimes not effectively treated with the currently available antiangiogenic treatments, suggesting the role of multiple pathways and molecular players. As such, pathological angiogenesis might be considered a joint venture of signaling pathways and molecular players, which cannot be controlled with a single blocker. This suggests that other players are also of prime importance, and not only VEGF-VGFR2 signaling. The hypoxiainduced choroidal angiogenesis model we proposed could be used to identity alternative molecular, signaling players in promoting angiogenesis, specifically in the CCs.

We have identified CCs and choroid vasculature in the developing embryos which lie in the posterior part of the eye. Physiological developmental angiogenesis is a requirement for all tissues in the body. The choriocapillaries are critical for vision as they are responsible for delivering up to $80 \%$ of oxygen and nutrients consumed by the retina, and all of that consumed by the photoreceptors ${ }^{189}$. In spite of this critical role in vision, developmental biology of these vasculatures are still poorly understood ${ }^{190}$. Disruption of their early development can lead to serious debilitating problems such a malnourishment of the eye and eventual blindness. A previous study suggest the primary role of VEGF produced by the RPE is critical for the normal development of the choroid ${ }^{189}$.

$\mathrm{CCs}$ in the zebrafish are unique in their structure, angiogenic properties and high density. We show that they develop via vasculogenesis unlike the retinal vessels which develops via sprouting angiogenesis ${ }^{168}$. Mechanism of CCs development in humans is via vasculogenesis/ angiogenesis in the early developmental stages ${ }^{174}$, which resembles the model we are presenting in the zebrafish. Accumulation of ECs in the outer eye field lead to formation of blood islands, which later transformed into tube like non-perfused vessels (Figure 10). These primitive vessels then mature and expand into an adult-like CC at $120 \mathrm{hpf}$. Interestingly, we did not find any evidence of intussusception during CCs development in the zebrafish, which is opposite in the CCs of the adult hypoxia model and CCs development in birds ${ }^{191}$ (Figure 10). Another important characteristic of these vessels is their development in a " $2 \mathrm{D}$ " plane and a synchronized developmental pattern. Such a developmental pattern could suggest the signaling pathways, which involve cytoskeletal remodeling important for sprouting, which is not observed in human patients of AMD with CNV ${ }^{23}$. Several questions arise when the development of these vessels are achieved via sprouting angiogenesis in the zebrafish while CNV involved in AMD is through intussusceptive angiogenesis. Careful investigation with timelapse video analysis of these vessels suggests continuous remodeling.

Retinal vessel develop in a 3D spatial area ${ }^{192}$ while we have shown that the CCs develops in a synchronized manner in a 2D plane. Such development of the CCs could be because of the protective abilities of the Bruch's membrane on one side, which will not allow the penetrations of the CCs in the retinal precincts, and a basement membrane on the other which will not allow CCs growth into the sclera. This is an important aspect which should be studied more thoroughly as disruptions within this developmental mechanism could be a major 
reason for the process of vessels penetrating into the retina as it occurs during CNV. The role of the rete mirabile (RM) has been shown to be important for exchange of gases, heat or chemical substances ${ }^{193}$. In humans, they are important because of their involvement is a condition called PHACE syndrome ${ }^{194}$. For the first time, we have identified RM in zebrafish; their discovery will lead to the possibility of finding new drugs, which might inhibit their development or growth and as such will be beneficial in controlling different types of CNVs in the ocular system, including ectopic development of the RM in patients with PHACE syndrome.

Inflammation and inflammatory pathways have been involved in the progression of pathological angiogenesis ${ }^{195,196}$. Anti-inflammatory drugs have shown to have potent antiangiogenic effects in pathological conditions such as in tumor associated neovascularization 197. There is a strong relationship between inflammation and angiogenesis and that is why, using only anti-angiogenic drugs is rarely effective in patients. A possible remedy of pathological angiogenesis would be a combination of both anti-inflammatory and antiangiogenic treatments. The pro-angiogenic role of inflammation is, however, considered to arise exclusively from recruitment and activation of immune cells, the role of inflammatory signaling pathways in the endothelial cells during angiogenesis remains poorly understood. We have used a specific IKK2 blocker to inhibit the downstream signaling of NF-kB pathway in the endothelial cells in vitro and in vivo, to see the effects on pathological and developmental angiogenesis. We observed that inhibiting the inflammatory responses using IKK2 selective blocker, IMD0354 inhibits the inflammatory responses as indicated by reduced expression of pro-inflammatory mediators i.e. chemokines and VEGF ${ }^{198}$. Consistent with our findings, corneal model of angiogenesis in the rats also shows restricted dilatation of the vessels, less angiogenic cells and productions of pro-angiogenic chemokines. These results are consistent with the previous findings in other tissues ${ }^{199,200}$. It was observed that VEGF-A is specifically involved in the whole scenario, and could be inhibited by blocking IKK2 as proven by qPCR, aortic ring assay and during the developmental angiogenesis by the zebrafish embryos and confirmed by other studies ${ }^{201}$.

Angiogenesis is a hallmark of many cancers, and is one of the cunning characteristics of the tumor cells 202,203 . Tumor cells have the ability to grow their tumors in size and metastasize 204. Among different tumor xenograft models, the zebrafish tumor xenograft model offers a range of benefits such as the ease of visualization of the tumor cells. Following implantation, the tumor growth can be studied in very high spatial and temporal details, evaluation of the number of disseminated cells across the whole embryo at the single-cell level, and pharmacological effects of the drugs can be tested on the zebrafish and tumors with ease 49 , ${ }^{130}$. Above all, zebrafish offers a variety of imaging techniques, which includes a time-lapse analysis of the moving tumor cells in a real time, following interaction of the tumor cells with the bloods vessels (Figure 6). Zebrafish does not hold an adaptive immune response at the embryonic stage, and can therefore not reject the tumor cells ${ }^{205}$.

Pigment epithelium-derived factor (PEDF) is a known anti-angiogenic factor in the eye 206 which was later confirmed to be an anti-angiogenic factor also in tumors ${ }^{207,208}$. We have 
shown that overexpression of PEDF leads to impaired dissemination of the tumor cells while inhibition increases the dissemination in the zebrafish. In contrast, melanocytes are regulated by microphthalmia-associated transcription factor (MITF) 209-211. Its functions varies in different situations such as the proliferation of the melanocytes is dependent upon slight expression of MITF ${ }^{212}$. In contrast the over expression of MITF leads to less aggressive melanoma cells ${ }^{213}$ while less expression of MITF will make the cells highly aggressive. It has been shown by others ${ }^{212,214-216}$ that overexpression of both PEDF and MITF depletes dissemination properties of melanocytes which we confirmed in our studies. The senescence in melanocytes shows a link between PEDF and MITF. Senescenced melanoma cells are associated with the silencing of MITF ${ }^{217,218}$. PEDF and MITF expression was down regulated by the induction of the senescence by oncogenes in the primary melanocytes. That is why the expression of MITF and PEDF were decreased in our sample of benign naevi; which are already considered senescent ${ }^{219,220}$. Taken together including the zebrafish tumor cell dissemination model we have identified the interlinked role between PEDF and MITF and show that the PEDF is regulated by MITF (Paper III).

Blood, supplies nourishment and oxygen to various tissues of the body ${ }^{221}$. Lack of oxygen and nutrients leads to serious pathological conditions such as ischemic heart diseases including myocardial infarction (MI), one of the most common causes of death today ${ }^{222,223}$. Patients with $\mathrm{MI}$ need to re-irrigate and regenerate their tissues, which is so far a very challenging approach. In order to achieve therapeutic angiogenesis certain pro-angiogenic factors or drugs with biocompatible materials should be used which helps in the tissue regeneration ${ }^{224}$. Another important challenge is the delivery of such products, as many current biomaterials used in regenerative medicine would require open heart surgery for implantation, which is a very invasive procedure that should be avoided if possible.

We have found an optimum concentration of collagen and alginate formulation converted into microspheres and embedded with cells or specific pro-angiogenic agents, proved their degradation abilities and the release of the proangiogenic FGF-2. This could be developed for use in the ischemic patients by administration of these microspheres via catheters. The fate of these microspheres and the cells/factors inside have been validated further using in vivo models of mouse and zebrafish. The science behind these biocompatible polymers is, however, still poor; it is needed to optimize various hydrogels for therapeutic use. Alginate and collagen were used as biocompatible polymers for a long time now because of their best regenerative properties towards the host tissues ${ }^{225-227}$. Collagen has been used in various biological preparations such as artificial cornea and has been helpful in the replacement of artificial graft ${ }^{226}$. Whereas, alginate is used in spinal cord regeneration in rats ${ }^{228}$. However, there are still drawbacks associated with both the polymers, such as higher solubility of collagen when subjected to biological fluids 226, 229, 230, we show that hydrogels with higher concentration of collagen disintegrates faster. On the other hand, hydrogels made mostly of alginate are stable in the living organisms ${ }^{231}$. Increasing the amount of alginate $(2: 1)$ to collagen, the hydrogels degradation is inhibited which is not an optimal alternative. Therefore, 
an optimum preparation (1:1) of both alginate and collagen is likely required for the physiological regeneration of the infarct tissues. More work is required to optimize and search for optimum degradation rate, the size of microspheres, which could be, injected easily. In addition, degradation rates of these polymers should be optimized to achieve normal physiological regeneration of the infarct tissues. Taken together these pharmaceutical, pharmacological and clinical problems, we need to find ways to formulate hydrogels as injectable microspheres and verify/test them in zebrafish. The aim should be to develop materials which would be easy to administer and will be effective in various treatment regimens. By using the zebrafish model, we have shown that it is possible to administer FGF2 in a patch or as microspheres of hydrogels in concentrations that are effective in providing angiogenic abilities. 


\section{CONCLUSIONS}

Zebrafish can be used in a variety of studies specifically for understanding the mechanism of angiogenesis in CNV during progression to wet AMD or angiogenesis related to tumor progression. The quest remains to improve our understanding of the exact mechanism behind these diseases. The search continues in finding better treatment strategies for these debilitating and serious diseases.

Identification of CCs in the zebrafish open new avenues to understand this particularly complex vascular tissue. Understanding the core mechanisms regulating these vessels and effects of hypoxia leading to intussusceptive angiogenesis and the involvement of VEGFVEGFR2 signaling together with other non-VEGF signaling pathways could be investigated in the future as targets for the development of new treatment strategies for CNV related AMD.

Sprouting angiogenesis is the main mode of vascular expansion during zebrafish CCS development, unlike, intussusception that is observed during adult pathological vessels remodeling. Development of CCS, requires VEGF-VEGFR signaling just like pathological remodeling. Similarly the RM could also be responsible for different pathologies of the eye (i.e. PHACE syndrome), a treatment of which might be possible after identification of factors regulating the formation of the RM in zebrafish.

Inflammation and angiogenesis are interlinked. Inflammatory pathways and factors are responsible for initiation or inhibition of angiogenic processes. Patients who do not respond to merely angiogenic drugs could be treated with synergistic drugs including both antiinflammatory and anti-angiogenic drugs. Similarly, by blocking IKK2 by IMD0354 we can treat serious debilitating eye diseases especially when used together with other anti-angiogenic drugs.

Zebrafish has emerged as a powerful tool for understanding debilitating diseases such as cancer and has helped researchers to understand complex mechanisms in cancer biology. Using this model system, we have shown that both PEDF and MITF regulate the progression and ultimately the metastasis of tumor cells.

Among many useful techniques offered by zebrafish, it can be used for testing the delivery of biocompatible polymers. The biggest challenge is to deliver the right therapeutic remedy to the right tissue. We have shown that FGF-2 laced hydrogels have potential as a pro-angiogenic therapy using, in combination with other techniques, angiogenesis assays in zebrafish embryos. 


\section{ACKNOWLEDGEMENTS}

Many people have helped me in completion of this journey. This work would not have been possible without the guidance and help of several individuals who have contributed and continued their valuable assistance for the success of this study. I would like to express my sincere gratitude to all of you. Special thank you to;

Lasse Dahl Ejby Jensen, my main supervisor, for trust in me, for giving me the freedom, for strengthening my confidence and being independent during these years. For believing in me and giving me an opportunity to work under your kind supervision. Thank you for your positive criticism, which ultimately made me who I am today! It was literally your hard work, passion and dedication which I followed all these years and gave me so much energy during all these years and still energetic! You are an inspiration for me, thank you for your endless help and support. Thank you for being there for me in all situations especially when I was stressed. You are not only a source of scientific knowledge, enthusiasm and optimism but you are my great mentor. You were so patient with me. I greatly appreciated when supervising me, you always took the time to break things down to a level that I could understand and then build upon. Assigning experimental tasks to me that were sometimes quite difficult and conducting JCMs allowed me to have the chance to expand my knowledge and build confidence in my abilities. I will always admire your energy and your persistence. Thank you for your guidance, encouragement and all support during the years.

Neil Lagali, my co-supervisor, for accepting to be my co-supervisor and mentor all these years. Your dedication and kind supervision have been always helpful to achieve my goals. I have learned quite allot from you. Thank you for your discussions in all those morning meetings. Thank you for sharing your scientific knowledge and to provide me with an idea to solve the problems during the years. Thank you for being an optimist, looking at the comforting prospectus of things and always giving of your precious time. Your wise advice in ophthalmology have been invaluable. Thank you for being so humbling and generous!

Yihai Cao, even though you are not my supervisor but I have learned so much from you, you are an inspiring and dedicated Professor. I have always followed your suggestions and your hard work. Thank you for all your encouragement, help and inspirations throughout these years. I will never forget your encouraging words "do you ever sleep! You work so hard!" Thank you very much for being with me in this journey.

Beatrice Bourghardt Peebo, although you are not my co-supervisor but I have learned allot from you in the discussions in various meetings. Thank you for being very helpful in all the discussions especially in the identifications of the zebrafish cornea. Thank you for all the advices you share with me in the conference and morning meetings. ARVO was my best conference I have ever attended! Thank you for being so positive, curious and full of enthusiasm. I really admire your intelligence, ability for all your work, sharing ideas and helping me during my research period. Thank you for discussions about everything and for always giving a helping hand when needed. 
Anthony Mukwaya, thank you very much for the endless support all these years. You have really helped me in all situations. We shared good times and tuff time together. We share great time in the conferences and study tours together and helped each other, but most importantly, you were there whenever and wherever I called you. Thank you for your unconditional support my friend! Which is still with me!

Anik Islam, for my lab friend, thank you for all the support and help from cell culturing lab and in general life! Thank you!

Maria Xerodaki, for very nice time together in all different courses we studied together, your help in all those courses and very nice time in the meetings and in the labs!

Pierfrancesco Mirabelli and Muthukumar Thangavelu for all the fun time together in meetings!

Anton Lennikov, for all your encouragement, you passion and dedication for science. Thank you for your help in the experiments, in lab and in general with allot of things, which will be a big list if I put it here. Thank you for all the scientific discussions in the JCMs, your inspirations and positive criticism that boosted my life in such a success.

To all the technical staff at CBR and the zebrafish core facility, special thanks to Andreas Linghammar, Jonas Andersson, Pernilla Strigner and Anna Fyrberg.

All our former students, thank you for the being supportive and productive all these years, special thanks to the pioneers of the zebrafish lab: Christofer Sahin, Jon Nilsson, Henrik Åsberg, and the former students Viktor Elmsjö, Sebastian Johansson, Erik Lindqvist, Natalia Sadowska, Cecilia Alexis Greder, Isak Mikkola, Marcus Norberg, Syed Umair bin Akhtar, Victor Silvestre Soto and Marle Georgina Kraft thank you very much!

Sebastian Gnosa, Na Liu, Chuanwen Fan, Maria Kopsida, Klang Årstrand Hanna, and Siyuwei Cao for wonderful time in the lab.

Gabriela Vazquez Rodriguez, for helping me with the time-lapse experiments and Annelie Abrahamsson with the tumor sample preparations.

Stig Linder and Jordi Altimiras for opponents on my half time seminar. Thank you very much for all your suggestions in my half time!

Former PhD students Emina Vorkapic, Ida Bergström, Therese Nilsson, Sandeep Koppal, Sudeep Chenna Narendra, Mahdi Amirhosseini and Ravi Kumar Dutta for fun fika times!

Elin Wistrand, Malin Strand and Madeleine Örlin for all the administrative works for me, you made my life so easy, thank you!

All KVM and LÄFO members and seniors, Rosanna Chung, Arjan Mofers, Padraig D'arcy, Beatrice Toia, Elena Faustini, Andrea Panza, Henrik Andersson, Ylva Böttiger, Karin Persson, Per Whiss, Eva Lund, Malin Lindqvist Appell, Anne Kunath, Karthik Selvaraj, Olivia Forsberg, Anna Zimdahl Kahlin, Daniel Söderberg, Ingrid Jakobsen Falk, Andreas Eriksson, Anna Lundberg, Anna Svedberg, Niclas Björn, Shahnawaz Alam, Hazal Yilmaz and Lucia Pelle thank you all for great fika times! 
Kajsa Bendtsen for all administrative work for me, thank you very much!

All Bioreperia colleagues, special thanks to Anna Nilsson, Malin Vildevall and Lina Wirestam. Thank you very much for great time together in the lab!

Technical staff at the core facility Åsa Schippert and Annette Molbaek for all the help and assistance with lab work, Thank you!

Vesa Loitto for helping with all the microscopic techniques and Maria Ntzouni for helping with TEM, thank you!

My PhD thesis committee, the faculty opponent Massimo Santoro, the examination board Zoltán Szabó, Anita Öst, Johan Ledin and Magnus Grenegård, thank you very much for being with me in this journey.

To my wife, sincere thanks to you for being right hand for me. You have helped me in this journey more than I thought! And I know how much you have supported me. Thank you for your endless support throughout my life. Thank you!

The pearls of my life are my kids Zunaira and Zahran, you are the only reason I could laugh and enjoy. You have given me the strength to fulfill my dreams. You are still very little but a time will come when you realize, everything is for you!

My Parents, thank you very much for the support, prayers and endless love for me. You have always been supportive for me! I love you so much!

My beloved uncle Ayyaz Ahmad, thank you very much for the endless help throughout my life, especially coming to Sweden was always easy with your support! Thank you very much!

My brothers, Salman Ali, Amjad Ali and Tayyab Ali thank you very much for your support throughout my life. Thank you very much for understanding my busy schedule $:$. 


\section{REFERENCES}

[1] Folkman J: Angiogenesis in cancer, vascular, rheumatoid and other disease. Nature medicine 1995, 1:27.

[2] Watanabe D, Suzuma K, Matsui S, Kurimoto M, Kiryu J, Kita M, Suzuma I, Ohashi H, Ojima T, Murakami T, Kobayashi T, Masuda S, Nagao M, Yoshimura N, Takagi H: Erythropoietin as a Retinal Angiogenic Factor in Proliferative Diabetic Retinopathy. New England Journal of Medicine 2005, 353:782-92.

[3] Hellman J, Yiu G: Age-Related Macular Degeneration. Vitreoretinal Disorders. Edited by Yiu G. Singapore: Springer Singapore, 2018. pp. 35-70.

[4] Folkman J: Angiogenesis: an organizing principle for drug discovery? Nat Rev Drug Discov 2007, 6:273-86.

[5] Williams DF, Williams DF: The Williams dictionary of biomaterials: Liverpool University Press, 1999.

[6] Poss KD, Wilson LG, Keating MT: Heart regeneration in zebrafish. Science 2002, 298:2188-90.

[7] Raya Á, Koth CM, Büscher D, Kawakami Y, Itoh T, Raya RM, Sternik G, Tsai H-J, Rodríguez-Esteban C, Izpisúa-Belmonte JC: Activation of Notch signaling pathway precedes heart regeneration in zebrafish. Proceedings of the National Academy of Sciences 2003, 100:11889-95.

[8] Martin DP, Williams SF: Medical applications of poly-4-hydroxybutyrate: a strong flexible absorbable biomaterial. Biochemical Engineering Journal 2003, 16:97-105.

[9] Stock UA, Nagashima M, Khalil PN, Nollert GD, Herden T, Sperling JS, Moran A, Lien J, Martin DP, Schoen FJ, Vacanti JP, Mayer JE: Tissue-engineered valved conduits in the pulmonary circulation. The Journal of Thoracic and Cardiovascular Surgery 2000, 119:732-40.

[10] von Frauhofer J, Chu C, von Fraunhofer J, Greisler H: Mechanical properties: CRC Press Boca Raton, FL, 1996.

[11] Demir R, Seval Y, Huppertz B: Vasculogenesis and angiogenesis in the early human placenta. Acta Histochemica 2007, 109:257-65.

[12] ten Dijke P, Arthur HM: Extracellular control of TGF $\beta$ signalling in vascular development and disease. Nature Reviews Molecular Cell Biology 2007, 8:857.

[13] Oprea Ş, Pantu C, Filipoiu F, Tulin R, Oprea GD: THE ANATOMY OF THE CHOROID-A REVIEW. Romanian Journal of Functional \& Clinical, Macro-\& Microscopical Anatomy \& of Anthropology/Revista Româna de Anatomie Functionala si Clinica, Macro si Microscopica si de Antropologie 2016, 15.

[14] Nickla DL, Wallman J: The multifunctional choroid. Progress in Retinal and Eye Research 2010, 29:144-68.

[15] Poukens V, Glasgow BJ, Demer JL: Nonvascular contractile cells in sclera and choroid of humans and monkeys. Investigative ophthalmology \& visual science 1998, 39:1765-74.

[16] Tobe T, Ortega S, Luna JD, Ozaki H, Okamoto N, Derevjanik NL, Vinores SA, Basilico C, Campochiaro PA: Targeted Disruption of the FGF2 Gene Does Not Prevent Choroidal Neovascularization in a Murine Model. The American Journal of Pathology 1998, 153:1641-6.

[17] Krzystolik MG, Afshari MA, Adamis AP, et al.: Prevention of experimental choroidal neovascularization with intravitreal anti-vascular endothelial growth factor antibody fragment. Archives of Ophthalmology 2002, 120:338-46.

[18] Grossniklaus HE, Gass JDM: Clinicopathologic correlations of surgically excised type 1 and type 2 submacular choroidal neovascular membranes. American Journal of Ophthalmology 1998, 126:59-69. [19] Lafaut BA, Bartz-Schmidt KU, Vanden Broecke C, Aisenbrey S, De Laey JJ, Heimann K: Clinicopathological correlation in exudative age related macular degeneration: Histological differentiation between classic and occult choroidal neovascularisation. British Journal of Ophthalmology 2000, 84:239-43.

[20] Jung JJ, Chen CY, Mrejen S, Gallego-Pinazo R, Xu L, Marsiglia M, Boddu S, Freund KB: The incidence of neovascular subtypes in newly diagnosed neovascular age-related macular degeneration. American journal of ophthalmology 2014, 158:769-79. e2. 
[21] Campochiaro PA, Soloway P, Ryan SJ, Miller JW: The pathogenesis of choroidal neovascularization in patients with age-related macular degeneration. Mol Vis 1999, 5:34-8. [22] Group MPS: Argon laser photocoagulation for senile macular degeneration. Results of a randomized clinical trial. Arch Ophthalmol 1982, 100:912-8.

[23] Jager RD, Mieler WF, Miller JW: Age-related macular degeneration. New England Journal of Medicine 2008, 358:2606-17.

[24] Kulkarni AD, Kuppermann BD: Wet age-related macular degeneration. Advanced Drug Delivery Reviews 2005, 57:1994-2009.

[25] Gass JDM: Drusen and disciform macular detachment and degeneration. Archives of Ophthalmology 1973, 90:206-17.

[26] Sarks SH: Ageing and degeneration in the macular region: a clinico-pathological study. British Journal of Ophthalmology 1976, 60:324-41.

[27] Smiddy WE, Fine SL: Prognosis of Patients with Bilateral Macular Drusen. Ophthalmology 1984, 91:271-7.

[28] Green WR, McDonnell PJ, Yeo JH: Pathologic Features of Senile Macular Degeneratlon. Ophthalmology 1985, 92:615-27.

[29] Bressler SB, Silva JC, Bressler NM, Alexander J, Green W: Clinicopathologic correlation of occult choroidal neovascularization in age-related macular degeneration. Archives of Ophthalmology 1992, 110:827-32.

[30] Heriot WJ, Henkind P, Bellhorn RW, Burns MS: Choroidal Neovascularization Can Digest Bruch's Membrane: A Prior Break is Not Essential. Ophthalmology 1984, 91:1603-8.

[31] Ryan SJ: Subretinal neovascularization: Natural history of an experimental model. Archives of Ophthalmology 1982, 100:1804-9.

[32] Leibowitz HM, Krueger D, Maunder L, Milton R, Kini M, Kahn H, Nickerson R, Pool J, Colton T, Ganley J: The Framingham Eye Study monograph: An ophthalmological and epidemiological study of cataract, glaucoma, diabetic retinopathy, macular degeneration, and visual acuity in a general population of 2631 adults, 1973-1975. Survey of ophthalmology 1980, 24:335-610.

[33] Piguet B, Wells JA, Palmvang IB, Wormald R, Chisholm IH, Bird AC: Age-related Bruch's membrane change: a clinical study of the relative role of heredity and environment. British Journal of Ophthalmology 1993, 77:400-3.

[34] Silvestri G, Johnston PB, Hughes AE: Is genetic predisposition an important risk factor in agerelated macular degeneration? Eye 1994, 8:564.

[35] Allikmets R, Shroyer NF, Singh N, Seddon JM, Lewis RA, Bernstein PS, Peiffer A, Zabriskie NA, Li Y, Hutchinson A, Dean M, Lupski JR, Leppert M: Mutation of the Stargardt Disease Gene (<em>ABCR</em>) in Age-Related Macular Degeneration. Science 1997, 277:1805-7.

[36] Hamdi HK, Kenney C: Age-related macular degeneration: a new viewpoint. Front Biosci 2003, 8:e305-e14.

[37] Zareparsi S, Reddick AC, Branham KEH, Moore KB, Jessup L, Thoms S, Smith-Wheelock M, Yashar BM, Swaroop A: Association of Apolipoprotein E Alleles with Susceptibility to Age-Related Macular Degeneration in a Large Cohort from a Single Center. Investigative Ophthalmology \& Visual Science 2004, 45:1306-10.

[38] Allikmets R: Simple and Complex ABCR: Genetic Predisposition to Retinal Disease. The American Journal of Human Genetics 2000, 67:793-9.

[39] Sellheyer K: Development of the choroid and related structures. Eye 1990, 4:255.

[40] Saint-Geniez M, D'Amore PA: Development and pathology of the hyaloid, choroidal and retinal vasculature. The International journal of developmental biology 2004, 48:1045-58.

[41] Hangai M, He S, Hoffmann S, Lim JI, Ryan SJ, Hinton DR: Sequential induction of angiogenic growth factors by TNF- $\alpha$ in choroidal endothelial cells. Journal of Neuroimmunology 2006, 171:45-56. [42] Burri PH, Hlushchuk R, Djonov V: Intussusceptive angiogenesis: Its emergence, its characteristics, and its significance. Developmental Dynamics 2004, 231:474-88.

[43] Djonov V, Schmid M, Tschanz SA, Burri PH: Intussusceptive angiogenesis: its role in embryonic vascular network formation. Circ Res 2000, 86:286-92. 
[44] Burri PH, Djonov V: Intussusceptive angiogenesis—the alternative to capillary sprouting. Molecular Aspects of Medicine 2002, 23:1-27.

[45] Losenkova K, Zuccarini M, Helenius M, Jacquemet G, Gerasimovskaya E, Tallgren C, Jalkanen S, Yegutkin GG: Endothelial cells cope with hypoxia-induced depletion of ATP via activation of cellular purine turnover and phosphotransfer networks. Biochimica et Biophysica Acta (BBA) - Molecular Basis of Disease 2018, 1864:1804-15.

[46] Semenza GL: Oxygen homeostasis. Wiley Interdisciplinary Reviews: Systems Biology and Medicine 2010, 2:336-61.

[47] Chakraborty D, Scott RL, Soares MJ: Hypoxia Signaling and Placental Adaptations. Hypoxia: Methods and Protocols. Edited by Huang LE. New York, NY: Springer New York, 2018. pp. 167-83. [48] Skuli N, Majmundar AJ, Krock BL, Mesquita RC, Mathew LK, Quinn ZL, Runge A, Liu L, Kim MN, Liang J: Endothelial HIF-2 $\alpha$ regulates murine pathological angiogenesis and revascularization processes. The Journal of clinical investigation 2012, 122:1427-43.

[49] Lee SLC, Rouhi P, Jensen LD, Zhang D, Ji H, Hauptmann G, Ingham P, Cao Y: Hypoxia-induced pathological angiogenesis mediates tumor cell dissemination, invasion, and metastasis in a zebrafish tumor model. Proceedings of the National Academy of Sciences 2009, 106:19485-90.

[50] Wang GL, Jiang B-H, Rue EA, Semenza GL: Hypoxia-inducible factor 1 is a basic-helix-loop-helixPAS heterodimer regulated by cellular $\mathrm{O} 2$ tension. Proceedings of the national academy of sciences 1995, 92:5510-4.

[51] Maxwell PH, Wiesener MS, Chang G-W, Clifford SC, Vaux EC, Cockman ME, Wykoff CC, Pugh CW, Maher ER, Ratcliffe PJ: The tumour suppressor protein VHL targets hypoxia-inducible factors for oxygen-dependent proteolysis. Nature 1999, 399:271.

[52] Vasudev NS, Selby PJ, Banks RE: Renal cancer biomarkers: the promise of personalized care. BMC medicine 2012, 10:112.

[53] Figlin RA, Rathmell WK, Rini BI: Renal cell carcinoma: translational biology, personalized medicine, and novel therapeutic targets: Springer Science \& Business Media, 2012.

[54] Shin DH, Li SH, Yang SW, Lee BL, Lee MK, Park JW: Inhibitor of nuclear factor-kappaB alpha derepresses hypoxia-inducible factor-1 during moderate hypoxia by sequestering factor inhibiting hypoxia-inducible factor from hypoxia-inducible factor $1 \alpha$. The FEBS journal 2009, 276:3470-80. [55] Semenza GL: HIF-1, O2, and the 3 PHDs: how animal cells signal hypoxia to the nucleus. Cell 2001, 107:1-3.

[56] Hirsilä M, Koivunen P, Günzler V, Kivirikko KI, Myllyharju J: Characterization of the human prolyl 4-hydroxylases that modify the hypoxia-inducible factor. Journal of Biological Chemistry 2003, 278:30772-80.

[57] Aragonés J, Jones DR, Martín S, San Juan MA, Alfranca A, Vidal F, Vara A, Mérida I, Landázuri MO: Evidence for the involvement of diacylglycerol kinase in the activation of hypoxia-inducible transcription factor 1 by low oxygen tension. Journal of Biological Chemistry 2001, 276:10548-55. [58] Chandel NS, McClintock DS, Feliciano CE, Wood TM, Melendez JA, Rodriguez AM, Schumacker PT: Reactive oxygen species generated at mitochondrial complex III stabilize hypoxia-inducible factor$1 \alpha$ during hypoxia a mechanism of $O 2$ sensing. Journal of Biological Chemistry 2000, 275:25130-8. [59] Gerald D, Berra E, Frapart YM, Chan DA, Giaccia AJ, Mansuy D, Pouysségur J, Yaniv M, MechtaGrigoriou F: JunD reduces tumor angiogenesis by protecting cells from oxidative stress. Cell 2004, 118:781-94.

[60] Emerling BM, Platanias LC, Black E, Nebreda AR, Davis RJ, Chandel NS: Mitochondrial Reactive Oxygen Species Activation of p38 Mitogen-Activated Protein Kinase Is Required for Hypoxia Signaling. Molecular and Cellular Biology 2005, 25:4853-62.

[61] Hirota K, Semenza GL: Rac1 activity is required for the activation of hypoxia-inducible factor 1. Journal of Biological Chemistry 2001, 276:21166-72.

[62] Shemirani B, Crowe DL: Hypoxic induction of HIF-1 $\alpha$ and VEGF expression in head and neck squamous cell carcinoma lines is mediated by stress activated protein kinases. Oral oncology 2002, 38:251-7. 
[63] Azimi I: The interplay between HIF-1 and calcium signalling in cancer. The International Journal of Biochemistry \& Cell Biology 2018, 97:73-7.

[64] Clauss M: Molecular biology of the VEGF and the VEGF receptor family. Seminars in thrombosis and hemostasis: Copyright $(2000$ by Thieme Medical Publishers, Inc., 333 Seventh Avenue, New York, NY 10001, USA. Tel.:+ 1 (212) 584-4662, 2000. pp. 561-70.

[65] Holmes DI, Zachary I: The vascular endothelial growth factor (VEGF) family: angiogenic factors in health and disease. Genome Biology 2005, 6:209.

[66] Rakic J-M, Lambert V, Devy L, Luttun A, Carmeliet P, Claes C, Nguyen L, Foidart J-M, Noël As, Munaut C: Placental Growth Factor, a Member of the VEGF Family, Contributes to the Development of Choroidal Neovascularization. Investigative Ophthalmology \& Visual Science 2003, 44:3186-93.

[67] Cross MJ, Claesson-Welsh L: FGF and VEGF function in angiogenesis: signalling pathways, biological responses and therapeutic inhibition. Trends in Pharmacological Sciences 2001, 22:201-7. [68] Papadopoulos N, Martin J, Ruan Q, Rafique A, Rosconi MP, Shi E, Pyles EA, Yancopoulos GD, Stahl N, Wiegand SJ: Binding and neutralization of vascular endothelial growth factor (VEGF) and related ligands by VEGF Trap, ranibizumab and bevacizumab. Angiogenesis 2012, 15:171-85.

[69] Ferrara N, Gerber H-P, LeCouter J: The biology of VEGF and its receptors. Nature medicine 2003, 9:669.

[70] Takahashi H, Shibuya M: The vascular endothelial growth factor (VEGF)/VEGF receptor system and its role under physiological and pathological conditions. Clinical science 2005, 109:227-41. [71] Cao Y: Positive and negative modulation of angiogenesis by VEGFR1 ligands. Sci Signal 2009, 2:re1-re.

[72] Alitalo K, Carmeliet P: Molecular mechanisms of lymphangiogenesis in health and disease. Cancer cell 2002, 1:219-27.

[73] Carmeliet P, Moons L, Luttun A, Vincenti V, Compernolle V, De Mol M, Wu Y, Bono F, Devy L, Beck H: Synergism between vascular endothelial growth factor and placental growth factor contributes to angiogenesis and plasma extravasation in pathological conditions. Nature medicine 2001, 7:575.

[74] Dumont DJ, Jussila L, Taipale J, Lymboussaki A, Mustonen T, Pajusola K, Breitman M, Alitalo K: Cardiovascular failure in mouse embryos deficient in VEGF receptor-3. Science 1998, 282:946-9.

[75] Tammela T, Zarkada G, Wallgard E, Murtomäki A, Suchting S, Wirzenius M, Waltari M, Hellström $M$, Schomber T, Peltonen R: Blocking VEGFR-3 suppresses angiogenic sprouting and vascular network formation. Nature 2008, 454:656.

[76] Tammela T, Zarkada G, Nurmi H, Jakobsson L, Heinolainen K, Tvorogov D, Zheng W, Franco CA, Murtomäki A, Aranda E: VEGFR-3 controls tip to stalk conversion at vessel fusion sites by reinforcing Notch signalling. Nature cell biology 2011, 13:1202.

[77] Cross MJ, Dixelius J, Matsumoto T, Claesson-Welsh L: VEGF-receptor signal transduction. Trends in Biochemical Sciences 2003, 28:488-94.

[78] Sandner P, Wolf K, Bergmaier U, Gess B, Kurtz A: Induction of VEGF and VEGF receptor gene expression by hypoxia: Divergent regulation $<$ em $>$ in vivo $</$ em $>$ and $<$ em $>$ in vitro $</$ em $>$. Kidney International 1997, 51:448-53.

[79] Ferrara N, Gerber H-P, LeCouter J: The biology of VEGF and its receptors. Nature Medicine 2003, 9:669.

[80] Saint-Geniez M, Kurihara T, Sekiyama E, Maldonado AE, D'Amore PA: An essential role for RPEderived soluble VEGF in the maintenance of the choriocapillaris. Proceedings of the National Academy of Sciences 2009, 106:18751-6.

[81] Olsson AK, Dimberg A, Kreuger J, Claesson-Welsh L: VEGF receptor signalling - in control of vascular function. Nature reviews Molecular cell biology 2006, 7:359-71.

[82] Olsson A-K, Dimberg A, Kreuger J, Claesson-Welsh L: VEGF receptor signalling? In control of vascular function. Nature reviews Molecular cell biology 2006, 7:359.

[83] Stephen Charnock-Jones D, Sharkey AM, Boocock CA, Ahmed A, Plevin R, Ferrara N, Smith SK: Vascular Endothelial Growth Factor Receptor Localization and Activation in Human Trophoblast and Choriocarcinoma Cells1. Biology of Reproduction 1994, 51:524-30. 
[84] Takahashi T, Shirasawa T, Miyake K, Yahagi Y, Maruyama N, Kasahara N, Kawamura T, Matsumura O, Mitarai T, Sakai O: Protein Tyrosine Kinases Expressed in Glomeruli and Cultured Glomerular Cells: Flt-1 and VEGF Expression in Renal Mesangial Cells. Biochemical and Biophysical Research Communications 1995, 209:218-26.

[85] Barleon B, Sozzani S, Zhou D, Weich HA, Mantovani A, Marme D: Migration of human monocytes in response to vascular endothelial growth factor (VEGF) is mediated via the VEGF receptor flt-1. Blood 1996, 87:3336-43.

[86] Katoh O, Tauchi H, Kawaishi K, Kimura A, Satow Y: Expression of the vascular endothelial growth factor (VEGF) receptor gene, KDR, in hematopoietic cells and inhibitory effect of VEGF on apoptotic cell death caused by ionizing radiation. Cancer Res 1995, 55:5687-92.

[87] Yang X, Cepko CL: Flk-1, a Receptor for Vascular Endothelial Growth Factor (VEGF), Is Expressed by Retinal Progenitor Cells. The Journal of Neuroscience 1996, 16:6089-99.

[88] Gerber H-P, Condorelli F, Park J, Ferrara N: Differential transcriptional regulation of the two vascular endothelial growth factor receptor genes Flt-1, but not Flk-1/KDR, is up-regulated by hypoxia. Journal of Biological Chemistry 1997, 272:23659-67.

[89] Waltenberger J, Mayr U, Pentz S, Hombach V: Functional upregulation of the vascular endothelial growth factor receptor KDR by hypoxia. Circulation 1996, 94:1647-54.

[90] Wilting J, Birkenhager R, Eichmann A, Kurz H, Martiny-Baron G, Marme D, McCarthy JE, Christ B, Weich HA: VEGF121 induces proliferation of vascular endothelial cells and expression of flk-1 without affecting lymphatic vessels of chorioallantoic membrane. Developmental biology 1996, 176:76-85. [91] Barleon B, Siemeister G, Martiny-Baron G, Weindel K, Herzog C, Marme D: Vascular endothelial growth factor up-regulates its receptor fms-like tyrosine kinase 1 (FLT-1) and a soluble variant of FLT1 in human vascular endothelial cells. Cancer Res 1997, 57:5421-5.

[92] Seetharam L, Gotoh N, Maru Y, Neufeld G, Yamaguchi S, Shibuya M: A unique signal transduction from FLT tyrosine kinase, a receptor for vascular endothelial growth factor VEGF. Oncogene 1995, 10:135-47.

[93] Waltenberger J, Claesson-Welsh L, Siegbahn A, Shibuya M, Heldin CH: Different signal transduction properties of KDR and Flt1, two receptors for vascular endothelial growth factor. The Journal of biological chemistry 1994, 269:26988-95.

[94] Yoshida A, Anand-Apte B, Zetter BR: Differential endothelial migration and proliferation to basic fibroblast growth factor and vascular endothelial growth factor. Growth factors (Chur, Switzerland) 1996, 13:57-64.

[95] Soker S, Takashima S, Miao HQ, Neufeld G, Klagsbrun M: Neuropilin-1 is expressed by endothelial and tumor cells as an isoform-specific receptor for vascular endothelial growth factor. Cell 1998, 92:735-45.

[96] Neufeld G, Cohen T, Gengrinovitch S, Poltorak Z: Vascular endothelial growth factor (VEGF) and its receptors. The FASEB Journal 1999, 13:9-22.

[97] Lu M, Adamis AP: Vascular endothelial growth factor gene regulation and action in diabetic retinopathy. Ophthalmology Clinics 2002, 15:69-79.

[98] Campochiaro PA: Retinal and choroidal neovascularization. Journal of cellular physiology 2000, 184:301-10.

[99] Kwak N, Okamoto N, Wood JM, Campochiaro PA: VEGF is major stimulator in model of choroidal neovascularization. Investigative ophthalmology \& visual science 2000, 41:3158-64.

[100] Aiello LP, Avery RL, Arrigg PG, Keyt BA, Jampel HD, Shah ST, Pasquale LR, Thieme H, Iwamoto MA, Park JE: Vascular endothelial growth factor in ocular fluid of patients with diabetic retinopathy and other retinal disorders. New England Journal of Medicine 1994, 331:1480-7.

[101] Krzystolik MG, Afshari MA, Adamis AP, Gaudreault J, Gragoudas ES, Michaud NA, Li W, Connolly E, O'neill CA, Miller JW: Prevention of experimental choroidal neovascularization with intravitreal anti-vascular endothelial growth factor antibody fragment. Archives of ophthalmology 2002, 120:338-46. 
[102] Tolentino MJ, Mcleod DS, Taomoto M, Otsuji T, Adamis AP, Lutty GA: Pathologic features of vascular endothelial growth factor-induced retinopathy in the nonhuman primate. American journal of ophthalmology 2002, 133:373-85.

[103] Adamis AP, Shima DT, Tolentino MJ, Gragoudas ES, Ferrara N, Folkman J, D'amore PA, Miller JW: Inhibition of vascular endothelial growth factor prevents retinal ischemia-associated iris neovascularization in a nonhuman primate. Archives of ophthalmology 1996, 114:66-71.

[104] Grossniklaus HE, Ling JX, Wallace TM, Dithmar S, Lawson DH, Cohen C, Elner VM, Elner SG, Sternberg Jr P: Macrophage and retinal pigment epithelium expression of angiogenic cytokines in choroidal neovascularization. Mol Vis 2002, 8:119-26.

[105] Hofman P, Blaauwgeers HG, Tolentino MJ, Adamis AP, Nunes Cardozo BJ, Vrensen GF, Schlingemann RO: VEGF-A induced hyperpermeability of blood-retinal barrier endothelium in vivo is predominantly associated with pinocytotic vesicular transport and not with formation of fenestrations. Current eye research 2000, 21:637-45.

[106] Lopez PF, Sippy BD, Lambert HM, Thach AB, Hinton DR: Transdifferentiated retinal pigment epithelial cells are immunoreactive for vascular endothelial growth factor in surgically excised agerelated macular degeneration-related choroidal neovascular membranes. Investigative ophthalmology \& visual science 1996, 37:855-68.

[107] Shen W, Yu M, Barry C, Constable I, Rakoczy P: Expression of cell adhesion molecules and vascular endothelial growth factor in experimental choroidal neovascularisation in the rat. British Journal of Ophthalmology 1998, 82:1063-71.

[108] Ferrara N, Mass RD, Campa C, Kim R: Targeting VEGF-A to Treat Cancer and Age-Related Macular Degeneration. Annual Review of Medicine 2007, 58:491-504.

[109] Rosenfeld PJ, Brown DM, Heier JS, Boyer DS, Kaiser PK, Chung CY, Kim RY: Ranibizumab for Neovascular Age-Related Macular Degeneration. New England Journal of Medicine 2006, 355:141931.

[110] Lichtlen P, Lam TT, Nork TM, Streit T, Urech DM: Relative Contribution of VEGF and TNF- $\alpha$ in the Cynomolgus Laser-Induced CNV Model: Comparing the Efficacy of Bevacizumab, Adalimumab, and ESBA105. Investigative Ophthalmology \& Visual Science 2010, 51:4738-45.

[111] Takeda A, Baffi JZ, Kleinman ME, Cho WG, Nozaki M, Yamada K, Kaneko H, Albuquerque RJC, Dridi S, Saito K, Raisler BJ, Budd SJ, Geisen P, Munitz A, Ambati BK, Green MG, Ishibashi T, Wright JD, Humbles AA, Gerard CJ, Ogura Y, Pan Y, Smith JR, Grisanti S, Hartnett ME, Rothenberg ME, Ambati J: CCR3 is a target for age-related macular degeneration diagnosis and therapy. Nature 2009, 460:225. [112] Chappelow AV, Kaiser PK: Neovascular Age-Related Macular Degeneration. Drugs 2008, 68:1029-36.

[113] Dolcet X, Llobet D, Pallares J, Matias-Guiu X: NF-kB in development and progression of human cancer. Virchows Archiv 2005, 446:475-82.

[114] Karin M, Ben-Neriah Y: Phosphorylation meets ubiquitination: the control of NF-kB activity. Annual review of immunology 2000, 18:621-63.

[115] Sun S-C: Non-canonical NF-kB signaling pathway. Cell Research 2010, 21:71.

[116] Hayden MS, Ghosh S: Shared principles in NF-kB signaling. Cell 2008, 132:344-62.

[117] Vallabhapurapu S, Karin M: Regulation and function of NF-KB transcription factors in the immune system. Annual review of immunology 2009, 27:693-733.

[118] Dejardin E: The alternative NF-KB pathway from biochemistry to biology: pitfalls and promises for future drug development. Biochemical pharmacology 2006, 72:1161-79.

[119] Williams RA, Timmis J, Qwarnstrom EE: Computational models of the NF-KB signalling pathway. Computation 2014, 2:131-58.

[120] Lieschke GJ, Currie PD: Animal models of human disease: zebrafish swim into view. Nature Reviews Genetics 2007, 8:353.

[121] Ward AC, Lieschke GJ: The zebrafish as a model system for human disease. Frontiers in bioscience : a journal and virtual library 2002, 7:d827-33.

[122] Amsterdam A, Hopkins N: Mutagenesis strategies in zebrafish for identifying genes involved in development and disease. Trends in Genetics 2006, 22:473-8. 
[123] Pichler FB, Laurenson S, Williams LC, Dodd A, Copp BR, Love DR: Chemical discovery and global gene expression analysis in zebrafish. Nature Biotechnology 2003, 21:879.

[124] Kimmel CB, Ballard WW, Kimmel SR, Ullmann B, Schilling TF: Stages of embryonic development of the zebrafish. Developmental Dynamics 1995, 203:253-310.

[125] Tavares B, Santos Lopes S: The Importance of Zebrafish in Biomedical Research. 2013 2013, 26:10.

[126] González-Rosa JM, Burns CE, Burns CG: Zebrafish heart regeneration: 15 years of discoveries. Regeneration 2017, 4:105-23.

[127] Gemberling M, Bailey TJ, Hyde DR, Poss KD: The zebrafish as a model for complex tissue regeneration. Trends in genetics : TIG 2013, 29:10.1016/j.tig.2013.07.003.

[128] Fadool JM, Dowling JE: Zebrafish: A model system for the study of eye genetics. Progress in Retinal and Eye Research 2008, 27:89-110.

[129] Kimmel RA, Dobler S, Schmitner N, Walsen T, Freudenblum J, Meyer D: Diabetic pdx1-mutant zebrafish show conserved responses to nutrient overload and anti-glycemic treatment. Scientific reports 2015, 5:14241.

[130] Rouhi P, Jensen LD, Cao Z, Hosaka K, Länne T, Wahlberg E, Steffensen JF, Cao Y: Hypoxiainduced metastasis model in embryonic zebrafish. Nature Protocols 2010, 5:1911.

[131] Wyatt RA, Trieu NPV, Crawford BD: Zebrafish Xenograft: An Evolutionary Experiment in Tumour Biology. Genes 2017, 8:220.

[132] Brown HK, Schiavone K, Tazzyman S, Heymann D, Chico TJA: Zebrafish xenograft models of cancer and metastasis for drug discovery. Expert Opinion on Drug Discovery 2017, 12:379-89.

[133] Staudt D, Stainier D: Uncovering the Molecular and Cellular Mechanisms of Heart Development Using the Zebrafish. Annual Review of Genetics 2012, 46:397-418.

[134] Sassen WA, Köster RW: A molecular toolbox for genetic manipulation of zebrafish. Advances in Genomics and Genetics 2015, 2015:151-63.

[135] Zhdanova IV, Wang SY, Leclair OU, Danilova NP: Melatonin promotes sleep-like state in zebrafish. Brain research 2001, 903:263-8.

[136] Cahill GM: Clock mechanisms in zebrafish. Cell and tissue research 2002, 309:27-34.

[137] Postlethwait JH, Woods IG, Ngo-Hazelett P, Yan YL, Kelly PD, Chu F, Huang H, Hill-Force A, Talbot WS: Zebrafish comparative genomics and the origins of vertebrate chromosomes. Genome research 2000, 10:1890-902.

[138] Vogelstein B, Kinzler KW: Cancer genes and the pathways they control. Nature Medicine 2004, 10:789.

[139] Haber DA, Settleman J: Drivers and passengers. Nature 2007, 446:145.

[140] Greenman C, Stephens P, Smith R, Dalgliesh GL, Hunter C, Bignell G, Davies H, Teague J, Butler A, Stevens C, Edkins S, O'Meara S, Vastrik I, Schmidt EE, Avis T, Barthorpe S, Bhamra G, Buck G, Choudhury B, Clements J, Cole J, Dicks E, Forbes S, Gray K, Halliday K, Harrison R, Hills K, Hinton J, Jenkinson A, Jones D, Menzies A, Mironenko T, Perry J, Raine K, Richardson D, Shepherd R, Small A, Tofts C, Varian J, Webb T, West S, Widaa S, Yates A, Cahill DP, Louis DN, Goldstraw P, Nicholson AG, Brasseur F, Looijenga L, Weber BL, Chiew Y-E, deFazio A, Greaves MF, Green AR, Campbell P, Birney E, Easton DF, Chenevix-Trench G, Tan M-H, Khoo SK, Teh BT, Yuen ST, Leung SY, Wooster R, Futreal PA, Stratton MR: Patterns of somatic mutation in human cancer genomes. Nature 2007, 446:153. [141] Ruggeri BA, Camp F, Miknyoczki S: Animal models of disease: Pre-clinical animal models of cancer and their applications and utility in drug discovery. Biochemical Pharmacology 2014, 87:15061.

[142] Ferrara N: Vascular Endothelial Growth Factor: Basic Science and Clinical Progress. Endocrine Reviews 2004, 25:581-611.

[143] Lam SH, Wu YL, Vega VB, Miller LD, Spitsbergen J, Tong Y, Zhan H, Govindarajan KR, Lee S, Mathavan S: Conservation of gene expression signatures between zebrafish and human liver tumors and tumor progression. Nature biotechnology 2006, 24:73.

[144] Liu S, Leach SD: Zebrafish Models for Cancer. Annual Review of Pathology: Mechanisms of Disease 2011, 6:71-93. 
[145] Marques IJ, Weiss FU, Vlecken DH, Nitsche C, Bakkers J, Lagendijk AK, Partecke LI, Heidecke CD, Lerch MM, Bagowski CP: Metastatic behaviour of primary human tumours in a zebrafish xenotransplantation model. BMC Cancer 2009, 9:128.

[146] Mione MC, Trede NS: The zebrafish as a model for cancer. Disease Models \&amp; Mechanisms 2010, 3:517-23.

[147] Thisse C, Zon LI: Organogenesis--heart and blood formation from the zebrafish point of view. Science 2002, 295:457-62.

[148] Weinstein BM: Vascular cell biology in vivo: a new piscine paradigm? Trends in cell biology 2002, 12:439-45.

[149] Ali Z, Wang J, Cao Y, Jensen LD: Methods for Studying Developmental Angiogenesis in Zebrafish. Handbook of Vascular Biology Techniques. Edited by Slevin M, McDowell G. Dordrecht: Springer Netherlands, 2015. pp. 195-207.

[150] Langer R, Peppas NA: Advances in biomaterials, drug delivery, and bionanotechnology. AIChE Journal 2003, 49:2990-3006.

[151] Langer R: Biomaterials in Drug Delivery and Tissue Engineering: One Laboratory's Experience. Accounts of Chemical Research 2000, 33:94-101.

[152] Lawson ND, Weinstein BM: In vivo imaging of embryonic vascular development using transgenic zebrafish. Developmental biology 2002, 248:307-18.

[153] Jin S-W, Beis D, Mitchell T, Chen J-N, Stainier DYR: Cellular and molecular analyses of vascular tube and lumen formation in zebrafish. Development 2005, 132:5199-209.

[154] Traver D, Paw BH, Poss KD, Penberthy WT, Lin S, Zon LI: Transplantation and in vivo imaging of multilineage engraftment in zebrafish bloodless mutants. Nature immunology 2003, 4:1238.

[155] Seiler C, Abrams J, Pack M: Characterization of zebrafish intestinal smooth muscle development using a novel sm22 $\alpha$-b promoter. Developmental Dynamics 2010, 239:2806-12.

[156] Whitesell TR, Kennedy RM, Carter AD, Rollins E-L, Georgijevic S, Santoro MM, Childs SJ: An $\alpha$ smooth muscle actin (acta2/asma) zebrafish transgenic line marking vascular mural cells and visceral smooth muscle cells. PloS one 2014, 9:e90590.

[157] Kikuchi K, Holdway JE, Major RJ, Blum N, Dahn RD, Begemann G, Poss KD: Retinoic acid production by endocardium and epicardium is an injury response essential for zebrafish heart regeneration. Developmental cell 2011, 20:397-404.

[158] Lenard A, Ellertsdottir E, Herwig L, Krudewig A, Sauteur L, Belting H-G, Affolter M: In vivo analysis reveals a highly stereotypic morphogenetic pathway of vascular anastomosis.

Developmental cell 2013, 25:492-506.

[159] Zygmunt T, Gay CM, Blondelle J, Singh MK, Flaherty KM, Means PC, Herwig L, Krudewig A, Belting $\mathrm{H}-\mathrm{G}$, Affolter M: Semaphorin-PlexinD1 signaling limits angiogenic potential via the VEGF decoy receptor sFlt1. Developmental cell 2011, 21:301-14.

[160] Herwig L, Blum Y, Krudewig A, Ellertsdottir E, Lenard A, Belting H-G, Affolter M: Distinct cellular mechanisms of blood vessel fusion in the zebrafish embryo. Current biology 2011, 21:1942-8.

[161] Sauteur L, Krudewig A, Herwig L, Ehrenfeuchter N, Lenard A, Affolter M, Belting H-G: Cdh5/VEcadherin promotes endothelial cell interface elongation via cortical actin polymerization during angiogenic sprouting. Cell reports 2014, 9:504-13.

[162] Gerri C, Marín-Juez R, Marass M, Marks A, Maischein H-M, Stainier DYR: Hif-1 $\alpha$ regulates macrophage-endothelial interactions during blood vessel development in zebrafish. Nature communications 2017, 8:15492.

[163] Marín-Juez R, Marass M, Gauvrit S, Rossi A, Lai S-L, Materna SC, Black BL, Stainier DYR: Fast revascularization of the injured area is essential to support zebrafish heart regeneration. Proceedings of the National Academy of Sciences 2016, 113:11237-42.

[164] Vanhollebeke B, Stone OA, Bostaille N, Cho C, Zhou Y, Maquet E, Gauquier A, Cabochette P, Fukuhara S, Mochizuki N: Tip cell-specific requirement for an atypical Gpr124-and Reck-dependent Wnt/ $\beta$-catenin pathway during brain angiogenesis. Elife 2015, 4:e06489.

[165] Rouhi P, Jensen LD, Cao Z, Hosaka K, Länne T, Wahlberg E, Steffensen JF, Cao Y: Hypoxiainduced metastasis model in embryonic zebrafish. Nature protocols 2010, 5:1911. 
[166] Jensen LD, Cao Z, Nakamura M, Yang Y, Bräutigam L, Andersson P, Zhang Y, Wahlberg E, Länne $\mathrm{T}$, Hosaka K: Opposing effects of circadian clock genes bmal1 and period 2 in regulation of VEGFdependent angiogenesis in developing zebrafish. Cell reports 2012, 2:231-41.

[167] Cao R, Jensen LD, Soll I, Hauptmann G, Cao Y: Hypoxia-induced retinal angiogenesis in zebrafish as a model to study retinopathy. PloS one 2008, 3:e2748.

[168] Cao R, Jensen LDE, Söll I, Hauptmann G, Cao Y: Hypoxia-induced retinal angiogenesis in zebrafish as a model to study retinopathy. PloS one 2008, 3:e2748.

[169] Jensen LDE, Cao R, Hedlund E-M, Söll I, Lundberg JO, Hauptmann G, Steffensen JF, Cao Y: Nitric oxide permits hypoxia-induced lymphatic perfusion by controlling arterial-lymphatic conduits in zebrafish and glass catfish. Proceedings of the National Academy of Sciences 2009:pnas.

0907608106.

[170] Ali Z, Jensen LD: Hypoxia-Induced Retinal Angiogenesis in Adult Zebrafish. Handbook of Vascular Biology Techniques. Edited by Slevin M, McDowell G. Dordrecht: Springer Netherlands, 2015. pp. 173-83.

[171] Cao Z, Jensen LD, Rouhi P, Hosaka K, Länne T, Steffensen JF, Wahlberg E, Cao Y: Hypoxiainduced retinopathy model in adult zebrafish. Nature protocols 2010, 5:1903.

[172] Jensen LD, Nakamura M, Bräutigam L, Li X, Liu Y, Samani NJ, Cao Y: VEGF-B-Neuropilin-1 signaling is spatiotemporally indispensable for vascular and neuronal development in zebrafish. Proceedings of the National Academy of Sciences 2015, 112:E5944-E53.

[173] Zouache MA, Eames I, Klettner CA, Luthert PJ: Form, shape and function: segmented blood flow in the choriocapillaris. Scientific Reports 2016, 6:35754.

[174] Lutty GA, Hasegawa T, Baba T, Grebe R, Bhutto I, McLeod DS: Development of the human choriocapillaris. Eye 2010, 24:408.

[175] Takei A, Ekström M, Mammadzada P, Aronsson M, Yu M, Kvanta A, André H: Gene transfer of prolyl hydroxylase domain 2 inhibits hypoxia-inducible angiogenesis in a model of choroidal neovascularization. Scientific reports 2017, 7:42546.

[176] Campochiaro PA: Molecular pathogenesis of retinal and choroidal vascular diseases. Progress in retinal and eye research 2015, 49:67-81.

[177] Bressler NM, Arnold J, Benchaboune M, Blumenkranz MS, Fish GE, Gragoudas ES, Lewis $H$, Schmidt-Erfurth U, Slakter JS, Bressler SB, Manos K, Hao Y, Hayes L, Koester J, Reaves A, Strong HA, Treatment of Age-Related Macular Degeneration with Photodynamic Therapy Study G: Verteporfin therapy of subfoveal choroidal neovascularization in patients with age-related macular degeneration: additional information regarding baseline lesion composition's impact on vision outcomes-TAP report No. 3. Archives of ophthalmology (Chicago, III : 1960) 2002, 120:1443-54.

[178] Cao Y: VEGF-targeted cancer therapeutics-paradoxical effects in endocrine organs. Nature reviews Endocrinology 2014, 10:530.

[179] Marín-Juez R, Marass M, Gauvrit S, Rossi A, Lai S-L, Materna SC, Black BL, Stainier DY: Fast revascularization of the injured area is essential to support zebrafish heart regeneration. Proceedings of the National Academy of Sciences 2016, 113:11237-42.

[180] Fraley ME, Rubino RS, Hoffman WF, Hambaugh SR, Arrington KL, Hungate RW, Bilodeau MT, Tebben AJ, Rutledge RZ, Kendall RL: Optimization of a pyrazolo [1, 5-a] pyrimidine class of KDR kinase inhibitors: improvements in physical properties enhance cellular activity and pharmacokinetics. Bioorganic \& medicinal chemistry letters 2002, 12:3537-41.

[181] Hao J, Ho JN, Lewis JA, Karim KA, Daniels RN, Gentry PR, Hopkins CR, Lindsley CW, Hong CC: In vivo structure- activity relationship study of dorsomorphin analogues identifies selective VEGF and BMP inhibitors. ACS chemical biology 2010, 5:245-53.

[182] Jensen LD, Rouhi P, Cao Z, Länne T, Wahlberg E, Cao Y: Zebrafish models to study hypoxiainduced pathological angiogenesis in malignant and nonmalignant diseases. Birth Defects Research Part C: Embryo Today: Reviews 2011, 93:182-93.

[183] Rouhi P, Lee SLC, Cao Z, Hedlund E-M, Jensen LD, Cao Y: Pathological angiogenesis facilitates tumor cell dissemination and metastasis. Cell Cycle 2010, 9:913-7. 
[184] Ali Z, Islam A, Sherrell P, Le-Moine M, Lolas G, Syrigos K, Rafat M, Jensen LD: Adjustable delivery of pro-angiogenic FGF-2 by alginate:collagen microspheres. Biology Open 2018, 7.

[185] Bibliowicz J, Tittle RK, Gross JM: Chapter 7 - Toward a Better Understanding of Human Eye Disease: Insights From the Zebrafish, Danio rerio. Progress in Molecular Biology and Translational Science. Edited by Chang KT, Min K-T. Academic Press, 2011. pp. 287-330.

[186] Penberthy WT, Shafizadeh E, Lin S: The zebrafish as a model for human disease. Front Biosci 2002, 7:D1439-D53.

[187] Alvarez Y, Cederlund ML, Cottell DC, Bill BR, Ekker SC, Torres-Vazquez J, Weinstein BM, Hyde $D R$, Vihtelic TS, Kennedy BN: Genetic determinants of hyaloid and retinal vasculature in zebrafish. BMC Developmental Biology 2007, 7:114.

[188] Schraermeyer U, Julien S, Biesemeier A, Bartz-Schmidt KU, Wolburg H: A new kind of labyrinthlike capillary is responsible for leakage from human choroidal neovascular endothelium, as investigated by high-resolution electron microscopy. Graefe's Archive for Clinical and Experimental Ophthalmology 2015, 253:681-9.

[189] Zhu M, Bai Y, Zheng L, Le Y-Z: Presence of RPE-Produced VEGF in a Timely Manner Is Critical to Choroidal Vascular Development. Boston, MA: Springer US, 2012. pp. 299-304.

[190] Grossniklaus HE, Green WR: Choroidal neovascularization. American journal of ophthalmology 2004, 137:496-503.

[191] Djonov V, Schmid M, Tschanz SA, Burri PH: Intussusceptive angiogenesis: its role in embryonic vascular network formation. Circulation research 2000, 86:286-92.

[192] Gore AV, Monzo K, Cha YR, Pan W, Weinstein BM: Vascular development in the zebrafish. Cold Spring Harbor perspectives in medicine 2012:a006684.

[193] Bataille B, Wager M, Lapierre F, Goujon JM, Buffenoir K, Rigoard P: The significance of the rete mirabile in Vesalius's work: an example of the dangers of inductive inference in medicine.

Neurosurgery 2007, 60:761-8.

[194] Chung J-I, Weon Y: Ophthalmic rete mirabile: the first angiographic documentation of embryonic ophthalmic collaterals in a patient with moyamoya disease: a case report. Interventional Neuroradiology 2008, 14:293-6.

[195] Engelhardt E, Toksoy A, Goebeler M, Debus S, Bröcker EB, Gillitzer R: Chemokines IL-8, GRO $\alpha$, MCP-1, IP-10, and mig are sequentially and differentially expressed during phase-specific infiltration of leukocyte subsets in human wound healing. American Journal of Pathology 1998, 153:1849-60. [196] Romagnani P, Lasagni L, Annunziato F, Serio M, Romagnani S: CXC chemokines: the regulatory link between inflammation and angiogenesis. Trends in Immunology 2004, 25:201-9.

[197] Masferrer JL, Leahy KM, Koki AT, Zweifel BS, Settle SL, Woerner BM, Edwards DA, Flickinger AG, Moore RJ, Seibert K: Antiangiogenic and Antitumor Activities of Cyclooxygenase-2 Inhibitors. Cancer Research 2000, 60:1306-11.

[198] Gong Y, Koh D-R: Neutrophils promote inflammatory angiogenesis via release of preformed VEGF in an in vivo corneal model. Cell and tissue research 2010, 339:437-48.

[199] Onai Y, Suzuki J-i, Kakuta T, Maejima Y, Haraguchi G, Fukasawa H, Muto S, Itai A, Isobe M: Inhibition of IKB phosphorylation in cardiomyocytes attenuates myocardial ischemia/reperfusion injury. Cardiovascular research 2004, 63:51-9.

[200] Sugita A, Ogawa H, Azuma M, Muto S, Honjo A, Yanagawa H, Nishioka Y, Tani K, Itai A, Sone S: Antiallergic and anti-inflammatory effects of a novel IKB kinase $\beta$ inhibitor, IMD-0354, in a mouse model of allergic inflammation. International archives of allergy and immunology 2009, 148:186-98. [201] Rousseau S, Houle F, Kotanides H, Witte L, Waltenberger J, Landry J, Huot J: Vascular endothelial growth factor (VEGF)-driven actin-based motility is mediated by VEGFR2 and requires concerted activation of stress-activated protein kinase 2 (SAPK2/p38) and geldanamycin-sensitive phosphorylation of focal adhesion kinase. Journal of Biological Chemistry 2000, 275:10661-72. [202] Suh DY: Understanding angiogenesis and its clinical applications. Annals of clinical and laboratory science 2000, 30:227-38.

[203] Fosslien E: Review: molecular pathology of cyclooxygenase-2 in cancer-induced angiogenesis. Annals of clinical and laboratory science 2001, 31:325-48. 
[204] Chambers AF, Groom AC, MacDonald IC: Dissemination and growth of cancer cells in metastatic sites. Nature Reviews Cancer 2002, 2:563.

[205] Cao Z, Jensen LD, Rouhi P, Hosaka K, Länne T, Steffensen JF, Wahlberg E, Cao Y: Hypoxiainduced retinopathy model in adult zebrafish. Nature Protocols 2010, 5:1903.

[206] Dawson DW, Volpert OV, Gillis P, Crawford SE, Xu H-J, Benedict W, Bouck NP: Pigment Epithelium-Derived Factor: A Potent Inhibitor of Angiogenesis. Science 1999, 285:245-8.

[207] Craword SE, Fitchev P, Veliceasa D, Volpert OV: The many facets of PEDF in drug discovery and disease: a diamond in the rough or split personality disorder? Expert Opinion on Drug Discovery 2013, 8:769-92.

[208] Becerra SP, Notario V: The effects of PEDF on cancer biology: mechanisms of action and therapeutic potential. Nature Reviews Cancer 2013, 13:258.

[209] Cheli Y, Ohanna M, Ballotti R, Bertolotto C: Fifteen-year quest for microphthalmia-associated transcription factor target genes. Pigment Cell \& Melanoma Research 2010, 23:27-40.

[210] Levy C, Khaled M, Fisher DE: MITF: master regulator of melanocyte development and melanoma oncogene. Trends in Molecular Medicine 2006, 12:406-14.

[211] Widlund HR, Fisher DE: Microphthalamia-associated transcription factor: a critical regulator of pigment cell development and survival. Oncogene 2003, 22:3035.

[212] Carreira S, Goodall J, Denat L, Rodriguez M, Nuciforo P, Hoek KS, Testori A, Larue L, Goding CR: Mitf regulation of Dia1 controls melanoma proliferation and invasiveness. Genes \& development 2006, 20:3426-39.

[213] Sáez-Ayala M, Montenegro MF, Sánchez-del-Campo L, Fernández-Pérez MP, Chazarra S, Freter R, Middleton M, Piñero-Madrona A, Cabezas-Herrera J, Goding CR, Rodríguez-López JN: Directed Phenotype Switching as an Effective Antimelanoma Strategy. Cancer Cell 2013, 24:105-19.

[214] Orgaz JL, Ladhani O, Hoek KS, Fernández-Barral A, Mihic D, Aguilera O, Seftor EA, Bernad A, Rodríguez-Peralto JL, Hendrix MJC, Volpert OV, Jiménez B: 'Loss of pigment epithelium-derived factor enables migration, invasion and metastatic spread of human melanoma'. Oncogene 2009, 28:4147.

[215] Sáez-Ayala M, Montenegro MF, Sánchez-del-Campo L, Fernández-Pérez MP, Chazarra S, Freter R, Middleton M, Piñero-Madrona A, Cabezas-Herrera J, Goding CR: Directed phenotype switching as an effective antimelanoma strategy. Cancer cell 2013, 24:105-19.

[216] Ladhani O, Sánchez-Martinez C, Orgaz JL, Jimenez B, Volpert OV: Pigment epithelium-derived factor blocks tumor extravasation by suppressing amoeboid morphology and mesenchymal proteolysis1,2. Neoplasia 2011, 13:633-42.

[217] Giuliano S, Cheli Y, Ohanna M, Bonet C, Beuret L, Bille K, Loubat A, Hofman V, Hofman P, Ponzio G, Bahadoran P, Ballotti R, Bertolotto C: Microphthalmia-Associated Transcription Factor Controls the DNA Damage Response and a Lineage-Specific Senescence Program in Melanomas. Cancer Research 2010, 70:3813-22.

[218] Strub T, Giuliano S, Ye T, Bonet C, Keime C, Kobi D, Le Gras S, Cormont M, Ballotti R, Bertolotto C, Davidson I: Essential role of microphthalmia transcription factor for DNA replication, mitosis and genomic stability in melanoma. Oncogene 2011, 30:2319.

[219] Bennett DC: Human melanocyte senescence and melanoma susceptibility genes. Oncogene 2003, 22:3063.

[220] Pollock PM, Harper UL, Hansen KS, Yudt LM, Stark M, Robbins CM, Moses TY, Hostetter G, Wagner U, Kakareka J, Salem G, Pohida T, Heenan P, Duray P, Kallioniemi O, Hayward NK, Trent JM, Meltzer PS: High frequency of BRAF mutations in nevi. Nature Genetics 2003, 33:19-20.

[221] Inayat MS, Bernard AC, Gallicchio VS, Garvy BA, Elford HL, Oakley OR: Oxygen carriers: A selected review. Transfusion and Apheresis Science 2006, 34:25-32.

[222] Antman E, Bassand J-P, Klein W, Ohman M, Lopez Sendon JL, Rydén L, Simoons M, Tendera M: Myocardial infarction redefined-a consensus document of The Joint European Society of Cardiology/American College of Cardiology committee for the redefinition of myocardial infarction: The Joint European Society of Cardiology/ American College of Cardiology Committee**A list of contributors to this ESC/ACC Consensus Document is provided in Appendix B. Journal of the American College of Cardiology 2000, 36:959-69. 
[223] Eltzschig HK, Eckle T: Ischemia and reperfusion-from mechanism to translation. Nature Medicine 2011, 17:1391.

[224] Emmert MY, Hitchcock RW, Hoerstrup SP: Cell therapy, 3D culture systems and tissue engineering for cardiac regeneration. Advanced Drug Delivery Reviews 2014, 69-70:254-69.

[225] Rufaihah AJ, Seliktar D: Hydrogels for therapeutic cardiovascular angiogenesis. Advanced drug delivery reviews 2016, 96:31-9.

[226] Rafat M, Xeroudaki M, Koulikovska M, Sherrell P, Groth F, Fagerholm P, Lagali N: Composite core-and-skirt collagen hydrogels with differential degradation for corneal therapeutic applications. Biomaterials 2016, 83:142-55.

[227] Leslie SK, Cohen DJ, Sedlaczek J, Pinsker EJ, Boyan BD, Schwartz Z: Controlled release of rat adipose-derived stem cells from alginate microbeads. Biomaterials 2013, 34:8172-84.

[228] Guenther MI, Weidner N, Müller R, Blesch A: Cell-seeded alginate hydrogel scaffolds promote directed linear axonal regeneration in the injured rat spinal cord. Acta biomaterialia 2015, 27:140-50. [229] Rafat M, Li F, Fagerholm P, Lagali NS, Watsky MA, Munger R, Matsuura T, Griffith M: PEGstabilized carbodiimide crosslinked collagen-chitosan hydrogels for corneal tissue engineering. Biomaterials 2008, 29:3960-72.

[230] Friess W: Collagen-biomaterial for drug delivery. European Journal of Pharmaceutics and Biopharmaceutics 1998, 45:113-36.

[231] Purcell EK, Seymour JP, Yandamuri S, Kipke DR: In vivo evaluation of a neural stem cell-seeded prosthesis. Journal of neural engineering 2009, 6:026005. 
Appendix: Publications and manuscripts used in this thesis 


\section{Papers}

The papers associated with this thesis have been removed for copyright reasons. For more details about these see:

http://urn.kb.se/resolve?urn=urn:nbn:se:liu:diva-153266 